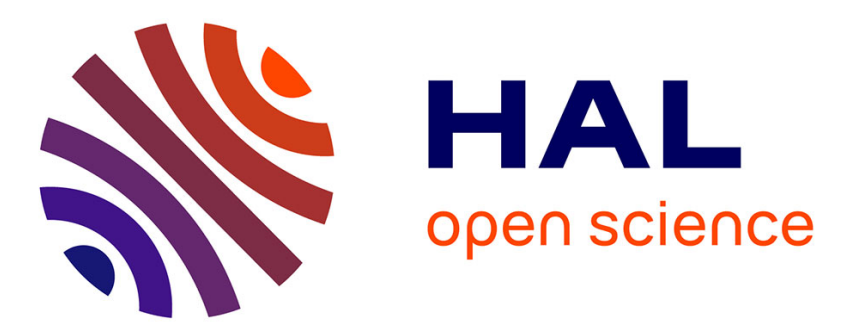

\title{
Biogenesis of Mercury-Sulfur Nanoparticles in Plant Leaves from Atmospheric Gaseous Mercury
}

Alain Manceau, Jianxu Wang, Mauro Rovezzi, Pieter Glatzel, Xinbin Feng

\section{To cite this version:}

Alain Manceau, Jianxu Wang, Mauro Rovezzi, Pieter Glatzel, Xinbin Feng. Biogenesis of MercurySulfur Nanoparticles in Plant Leaves from Atmospheric Gaseous Mercury. Environmental Science and Technology, 2018, 52 (7), pp.3935-3948. 10.1021/acs.est.7b05452 . hal-02314769

\section{HAL Id: hal-02314769 https://hal.science/hal-02314769}

Submitted on 13 Oct 2019

HAL is a multi-disciplinary open access archive for the deposit and dissemination of scientific research documents, whether they are published or not. The documents may come from teaching and research institutions in France or abroad, or from public or private research centers.
L'archive ouverte pluridisciplinaire HAL, est destinée au dépôt et à la diffusion de documents scientifiques de niveau recherche, publiés ou non, émanant des établissements d'enseignement et de recherche français ou étrangers, des laboratoires publics ou privés. 


\section{Biogenesis of Mercury-Sulfur Nanoparticles in Plant Leaves from}

\section{Atmospheric Gaseous Mercury}

4 Alain Manceau, ${ }^{* \dagger}$ Jianxu Wang, ${ }^{\dagger}$ Mauro Rovezzi,${ }^{\S}$ Pieter Glatzel, ${ }^{\S}$ Xinbin Feng ${ }^{*} \pitchfork$

6 †ISTerre, Université Grenoble Alpes, CNRS, CS 40700, 38058 Grenoble, France

$7 \quad$ State Key Laboratory of Environmental Geochemistry, Institute of Geochemistry, Chinese

8 Academy of Sciences, Guiyang 550081, People’s Republic of China

$9{ }^{\S}$ European Synchrotron Radiation Facility (ESRF), 71 Rue des Martyrs, 38000 Grenoble, France.

11 *To whom correspondence should be addressed. E-mail: alain.manceau@univ-grenoble-alpes.fr;

12 fengxinbin@vip.skleg.cn

13 Contacts : Alain Manceau: +33 (0)4 766351 93; Xinbin Feng: +86 85185895728

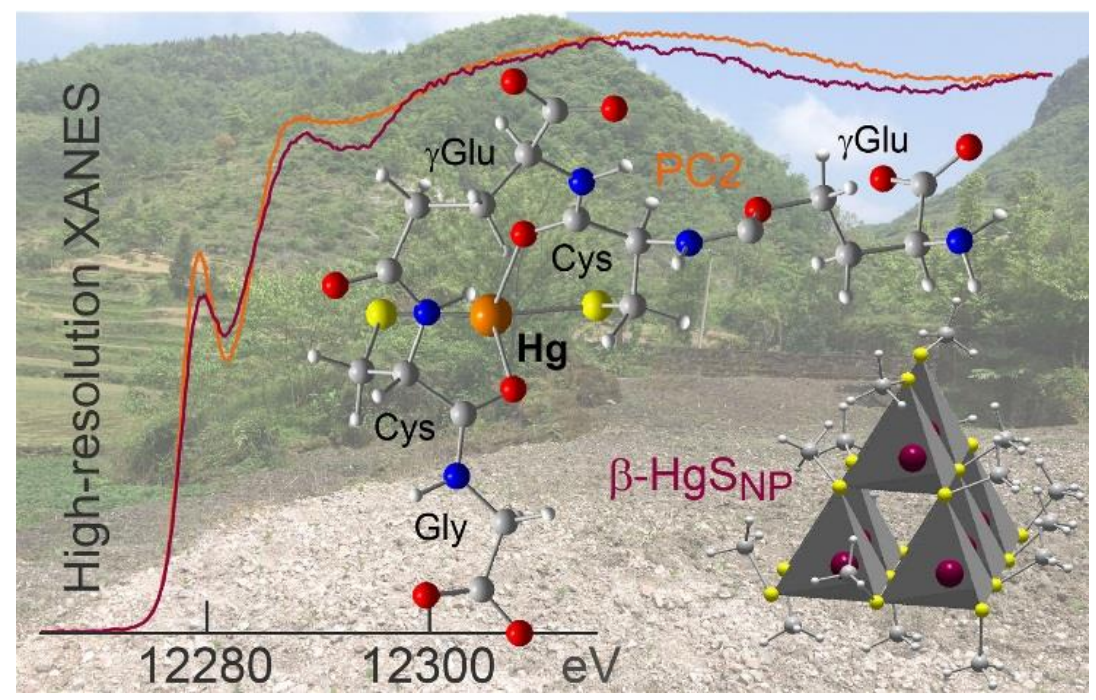

18 ABSTRACT: Plant leaves serve both as a sink for gaseous elemental mercury ( $\mathrm{Hg})$ from the 19 atmosphere and a source of toxic mercury to terrestrial ecosystems. Litterfall is the primary 
deposition pathway of atmospheric $\mathrm{Hg}$ to vegetated soils, yet the chemical form of this major $\mathrm{Hg}$

21 input remains elusive. We report the first observation of in vivo formation of mercury sulfur nanoparticles in intact leaves of 22 native plants from six different species across two sampling areas from China. The plants grew naturally in soils from a mercury sulfide mining and retorting region at ambient-air gaseous- $\mathrm{Hg}$ concentrations ranging from $131 \pm 19 \mathrm{ng} \mathrm{m}^{-3}$ to $636 \pm 186 \mathrm{ng} \mathrm{m}^{-}$ ${ }^{3}$ and had foliar $\mathrm{Hg}$ concentration between 1.9 and $31.1 \mathrm{ng} \mathrm{Hg} \mathrm{mg}^{-1}$ dry weight (ppm). High energyresolution X-ray absorption near-edge structure (HR-XANES) spectroscopy shows that up to 57\%

27 of the acquired $\mathrm{Hg}$ is nanoparticulate, and the remainder speciated as a bis-thiolate complex $\left(\mathrm{Hg}(\mathrm{SR})_{2}\right)$. The fractional amount of nanoparticulate $\mathrm{Hg}$ is not correlated with $\mathrm{Hg}$ concentration. Variation likely depends on leaf age, plant physiology, and natural variability. Nanoparticulate $\mathrm{Hg}$ atoms are bonded to four sulfide or thiolate sulfur atoms arranged in a metacinnabar-type $(\beta-\mathrm{HgS})$ coordination environment. The nanometer dimension of the mercury-sulfur clusters outmatches the known binding capacity of plant metalloproteins. These findings give rise to challenging questions on their exact nature, how they form, and their biogeochemical reactivity and fate in litterfall, whether this mercury pool is recycled or stored in soils. This study provides new evidence that metacinnabar-type nanoparticles are widespread in oxygenated environments.

\section{INTRODUCTION}

38 Plant foliage takes up gaseous elemental mercury $\left(\mathrm{Hg}^{0} \mathrm{~g}\right)$ from the atmosphere. This is followed by

39 litterfall or ingestion of leaves, so this is a primary deposition pathway on vegetated land and a 40 main trophic source of mercury. ${ }^{1-11}$ The chemical form this atmospheric mercury takes in leaf tissue 41 is of both fundamental and practical interest. From the fundamental perspective, chelation and 42 sequestration of metals by particular ligands is the molecular mechanism by which plants cope with 43 metal stress. Therefore, knowing how mercury undergoes biotransformation is critical to understanding how it is detoxified in response to exposure. Given how toxic mercury is to biota, we also need to know in which form divalent mercury $(\mathrm{Hg}(\mathrm{II}))$ enters terrestrial ecosystems and is metabolically processed at the next trophic level by detritus feeders and herbivors. Practical 
motivations include knowing how we can apply phytotechnology to remediate contamination, ${ }^{12-17}$

48 and using plants (e.g., tree barks and lichens) for present and retrospective monitoring of airborne 49 mercury. ${ }^{18,19}$

50 The only available speciation study on natural leaves is for Marrubium vulgare (Horehound)

51 from two $\mathrm{Hg}$-polluted soils near a cinnabar $(\alpha-\mathrm{HgS})$ mining site in Spain. There the leaf $\mathrm{Hg}$ concentration was 61 and $183 \mathrm{ng} \mathrm{Hg} \mathrm{mg}^{-1}$ dry weight (ppm dwt). ${ }^{20}$ Cinnabar, metacinnabar $(\beta$ -

$53 \mathrm{HgS}$ ), and a Hg-biothiol complex (Hg-SR) were identified using L3-edge extended X-ray absorption fine structure (EXAFS) spectroscopy. The two sulfide minerals were considered to be 55 soil microparticles deposited on the leaves. Thiol sulfur $\mathrm{Hg}$-binding ligands, interpreted as cysteine residues, were also identified from ex situ experiments with added mercury. ${ }^{20,21}$ Phytochelatins $\left(\mathrm{PCn}=(\gamma \mathrm{Glu}-\mathrm{Cys})_{\mathrm{n}}-\mathrm{Gly}\right)$, which are oligomers of glutathione $(\mathrm{GSH}=\gamma \mathrm{Glu}-\mathrm{Cys}-\mathrm{Gly})$ that mediate metal detoxification, ${ }^{22-25}$ are the only mercury ligands that have been characterized chemically, also with added mercury, using high-performance liquid chromatography coupled to high-resolution mass spectrometry (HPLC-MS). ${ }^{26-28}$ Mercury complexes with PC2 and PC3 were identified in

61 leaves of Arabidopsis thaliana exposed to thirty micromolar $\mathrm{HgCl}_{2}$ for one and two days yielding an uncommonly high leaf content of $400 \mathrm{ng} \mathrm{Hg} \mathrm{mg}{ }^{-1} \mathrm{dwt}^{29}{ }^{29} \mathrm{No} \mathrm{Hg}-\mathrm{PC}$ complex was detected at 63 the environmentally relevant leaf content of $15-20 \mathrm{ng} \mathrm{Hg} \mathrm{mg}^{-1}$ dwt with three micromolar $\mathrm{HgCl}_{2}$, 64 and no metal-PC complex has been identified to date in plants grown in the wild.

Absolute identification of the exact forms of metals occurring naturally in plant tissues, cells, and organelles remains a major analytical challenge. While HPLC-MS is excellent at molecular characterization of chemically extractable species, it is difficult to conserve the in vivo species in the plant extract during sample preparation and analysis. ${ }^{28,30-32}$ Also, mass spectrometric analyses

69 detect soluble biomolecules, not biominerals. ${ }^{33}$ In contrast, with X-ray absorption spectroscopy 70 such as EXAFS and X-ray absorption near-edge structure (XANES), we can quantify mixed 71 organic and inorganic forms directly on the solid, ${ }^{34,35}$ although with lower sensitivity to molecular 72 identity and elemental concentration than HPLC-MS. Typically, X-ray techniques provide the 
bonding environment(s) of the metal with a current bulk detection limit for mercury in plants of about $10 \mathrm{ng} \mathrm{mg}^{-1} \mathrm{dwt}$ for XANES and $50 \mathrm{ng} \mathrm{mg}^{-1} \mathrm{dwt}_{\text {for EXAFS. }}{ }^{17}, 19-21,36-42 \mathrm{In}^{2}$ most cases, wellcrystallized mineral species, such as $\alpha / \beta-\mathrm{HgS}$, can be differentiated, but $\mathrm{Hg}$ complexes with similar coordination cannot. Moreover, the chemical nature of the complexing molecule cannot be obtained unambiguously because the structural information is local, being limited to about $5 \AA$ beyond the metal atom of interest.

To collectively tackle detection limit, sensitivity to mercury coordination, and insight into the nature of the complexing molecule, we applied a four-pronged approach. First, we collected leaves from 22 plants from the heavily mined Guizhou province in southwest China, ${ }^{5}$ where the concentration of total elemental gaseous mercury commonly exceeds $50 \mathrm{ng} \mathrm{m}^{-3}$ in ambient air and typically reaches several tens of $\mu \mathrm{g} \mathrm{m}^{-3}$ near artisanal mercury smelters. ${ }^{8}{ }^{43}$ It has been estimated that emissions of $\mathrm{Hg}$ from this region to the global atmosphere accounted for $12 \%$ of the world total anthropogenic emissions. ${ }^{44}$ The unique collection of plant leaves comprises eight Pteris vittata ferns $\left(7.6 \mathrm{ng} \mathrm{mg}^{-1}<[\mathrm{Hg}]<31.1 \mathrm{ng} \mathrm{mg}^{-1}\right)$, two flowering plants $\left(4.5\right.$ and $\left.12.5 \mathrm{ng} \mathrm{Hg} \mathrm{mg}{ }^{-1}\right)$, ten shrubs $\left(4.4 \mathrm{ng} \mathrm{mg}^{-1}<[\mathrm{Hg}]<30.2 \mathrm{ng} \mathrm{Hg} \mathrm{mg}^{-1}\right)$, and two trees $\left(1.9\right.$ and $\left.4.9 \mathrm{ng} \mathrm{Hg} \mathrm{mg}^{-1}\right)$. Second, we developed a new high-luminosity multi-analyzer spectrometer for measuring XANES spectra at high energy-resolution (HR-XANES) in environmental inorganic and biological systems down to, and below, the ppm $\mathrm{Hg}$ level. ${ }^{45}$ The capability of this new instrument, demonstrated earlier for the characterization of mercury binding in scalp hair, ${ }^{46}$ is documented here for the first time on plants. The gain in spectral resolution provides superior distinction of $\mathrm{C}, \mathrm{N}, \mathrm{O}$, and $\mathrm{S}$ ligands. ${ }^{46-48}$ Third, we built a large spectral database of mercury minerals and coordination complexes against which to compare the leaf HR-XANES spectra. Fourth, the geometries of mercury-cysteine clusters were computed at a high level of molecular orbital theory to help in distinguishing biothiol from mercury sulfide forms.

The article describes our work as follows. First, we present the concentrations of $\mathrm{Hg}_{\mathrm{g}}^{0}$ in ambient air and total $\mathrm{Hg}$ in the 22 plants and in two plants grown in chambers with controlled $\mathrm{Hg}^{0}$ g levels. 
Next we determine the particulate forms of mercury in the mined ore and surrounding soils, which

100 may come into contact with the leaf tissues based on comparing HR-XANES spectra and linear 101 combinations of reference spectra. ${ }^{34}$ Then we derive the variability of the $\mathrm{Hg}$ chemical forms

102 among the leaves from the variance in the HR-XANES dataset as determined by principal 103 component analysis (PCA). ${ }^{49}$ We show that the complete set of leaf spectra can be described 104 statistically with only three abstract components, interpreted to indicate that three distinct chemical 105 forms are dominant. Two of the three forms are dithiolate complexes $\left(\operatorname{Hg}(\mathrm{SR})_{2}\right)$, one being new, 106 and the third form is a multinuclear cluster of $\mathrm{Hg}(\mathrm{II})$ and sulfur atoms. We calculate the fractional 107 amount of each $\mathrm{Hg}$ form in leaves by fitting linear combinations of spectra representing the pure $108 \mathrm{Hg}$ species to the dataset. Lastly, we discuss the nature of the multinuclear $\mathrm{Hg}$ species, a $\mathrm{Hg}(\mathrm{II})-$ 109 cysteinate complex of plant metallothionein $\left(\mathrm{Hg}_{\mathrm{x}}(\mathrm{Cys})_{\mathrm{y}}\right)$ or a nanosized mercury sulfide mineral, 110 and add complementary structural and molecular insights from first-principles calculations. ${ }^{50-53}$

\section{MATERIALS AND METHODS}

113 Materials. A detailed description of the Wuchuan and Wanshan sampling sites from the 114 Guizhou province, $\mathrm{Hg}_{\mathrm{g}}^{0}$ exposition experiment, mercury chemical analysis, and samples 115 preparation for HR-XANES measurment is given in Supporting Information (SI). The HR-XANES 116 spectra from the $\mathrm{Hg}$ ore, soils, and plant leaves were analyzed against a large spectral database of

117 mercury minerals ( $\alpha-\mathrm{HgS}, \beta-\mathrm{HgS}$, nanosized $\beta-\mathrm{HgS}), \mathrm{Hg}(\mathrm{II})$ complexes on natural organic matter 118 (Hg-NOM), and $\mathrm{Hg}(\mathrm{II})$ and methylmercury (MeHg) model complexes with thiolate ligands. ${ }^{46,47,53}$ 119 This database was completed for this study with $\mathrm{Hg}$ (II) complexed to L-GSH ( $\gamma$-Glu-Cys-Gly, $\mathrm{M}_{\mathrm{m}}$ $120=307.3 ;$ CAS = 70-18-8; Sigma-Aldrich), phytochelatin (PC; GeneCust Europe), metallothionein 121 (MT), and the zwitterionic thiol ligand TabH (4-(trimethylammonio)benzenethiol). ${ }^{54}$

122 HR-XANES Spectroscopy. All $\mathrm{Hg}$ L3-edge HR-XANES spectra were measured in high 123 energy-resolution fluorescence yield detection mode with high-luminosity analyzer crystals ${ }^{45}$ on 
124 beamline ID26 at the European Synchrotron Radiation Facility (ESRF). Detailed information on 125 data acquisition and analysis is given in the SI.

126 Computational Methodology. Geometry optimization of $\mathrm{Hg}_{\mathrm{x}} \mathrm{S}_{\mathrm{y}}$ clusters and $\mathrm{Hg}$ complexes 127 were performed at the second-order Møller-Plesset perturbation theory $\left(\mathrm{MP}^{25}\right.$ ) level with ORCA $128 \quad 3.0 .3^{56}$ and a computational scheme tested previously on the modeling of the structure and stability 129 of monomeric $\mathrm{Hg}$-thiolate complexes. ${ }^{46,47,52,53,57}$

\section{RESULTS}

Mercury concentration. Ambient air $\mathrm{Hg}_{\mathrm{g}}^{0}$ concentrations are in the range of $143 \pm 41 \leq \mathrm{Hg}_{\mathrm{g}}{ }_{\mathrm{g}}$

$133 \leq 432 \pm 122 \mathrm{ng} \mathrm{m}^{-3}$ at the Wuchuan sampling sites and $131 \pm 19 \leq \mathrm{Hg}_{\mathrm{g}}^{0} \leq 636 \pm 186 \mathrm{ng} \mathrm{m}^{-3}$ at the 134 Wanshan sampling sites (Figure 1a and SI Table S1). These concentrations are well within levels 135 reported previously in the two mining districts. ${ }^{8,43}$ Ore-roasting and soil re-emission of previously 136 deposited mercury are the main local source of $\mathrm{Hg}^{0}{ }_{\mathrm{g}} .{ }^{8},{ }^{8}$ Ground-to-air fluxes are extremely 137 variable. Spatial and temporal influences, such as proximity and $\mathrm{Hg}$ concentration at the point 138 source (mine, soil, roasting site) and ore processing activity, and variation in $\mathrm{Hg}$ response to 139 environmental variables and processes, such as photoreduction at the soil surface, can adequately 140 account for the mean variations in measured $\mathrm{Hg}_{\mathrm{g}}^{0}$ from site to site. Consecutive measurements of $141 \mathrm{Hg}^{0}$ at each sampling site for 20 to $30 \mathrm{~min}$ with a time resolution of $15 \mathrm{~s}$ show large standard 142 variation of the mean values, even at a short time-scale, which supports this (SI Table S2).

143 Foliar $\mathrm{Hg}$ concentrations vary from 1.9 to $31.1 \mathrm{ng} \mathrm{mg}^{-1}$, also without significant difference 144 between the Wuchuan $\left(4.4 \leq \mathrm{Hg} \leq 31.1 \mathrm{ng} \mathrm{mg}^{-1}\right)$ and the Wanshan $\left(1.9 \leq \mathrm{Hg} \leq 29.5 \mathrm{ng} \mathrm{mg}^{-1}\right)$ 145 sampling sites (Figure 1a and SI Table S1). To make a comparison with crops, Hg concentrations 146 between 0.2 and $0.8 \mathrm{ng} \mathrm{mg}^{-1}$ were measured in cole and tobacco leaves from the Wuchuan mining 147 area. ${ }^{59}$ The lowest concentration was observed for the evergreen coniferous Platycladus orientalis 148 (named Po2 where the number represents $[\mathrm{Hg}]$ in $\mathrm{ppm}$ ) collected at $\mathrm{Hg}_{\mathrm{g}}^{0}$ of $143 \pm 41 \mathrm{ng} \mathrm{m} \mathrm{m}^{-3}$, and 149 the highest concentration for the $P$. vittata fern (Pv31) collected at $\mathrm{Hg}_{\mathrm{g}}^{0}$ of $432 \pm 122 \mathrm{ng} \mathrm{m}^{-3}$. There 
150 is no trend in foliar $\mathrm{Hg}$ concentration as a function of plant species, $\mathrm{Hg}_{\mathrm{g}}{ }_{\mathrm{g}}$, or sampling site (Figure

151 1a). Previous studies have linked the $\mathrm{Hg}$ level in foliar tissue of the same species to the age of the

152 leaf, ${ }^{10,60-63}$ with concentration increasing steadily throughout the season and more rapidly during

153 high photosynthetic activity. ${ }^{64}$ This data was not measured due to time limitations and because our

154 main objective was to survey the chemical forms of $\mathrm{Hg}$ among a large variety of plant species, not

155 to examine how they evolved over time in any particular plant.

156 A sense of the extent of $\mathrm{Hg}$ loading with time is informed from P. vittata and Zea mays (corn)

157 grown in a greenhouse at $\mathrm{Hg}_{\mathrm{g}}^{0}$ concentration of $1000-1500 \mathrm{ng} \mathrm{m}^{-3}$ (SI). For P. vittata, foliar $\mathrm{Hg}$

158 concentration was $0.09 \mathrm{ng} \mathrm{mg}^{-1}$ before exposure, $0.12 \mathrm{ng} \mathrm{mg}^{-1}$ after 7 days, $0.57 \mathrm{ng} \mathrm{mg}^{-1}$ after 20

159 days, and $2.2 \mathrm{ng} \mathrm{mg}^{-1}$ after 28 days. For Z. mays it was $0.05 \mathrm{ng} \mathrm{mg}^{-1}$ initially, $0.07 \mathrm{ng} \mathrm{mg}^{-1}$ after 7

160 days, $0.52 \mathrm{ng} \mathrm{mg}^{-1}$ after 20 days, and $2.9 \mathrm{ng} \mathrm{mg}^{-1}$ after 28 days. P. vittata contained about 20 times

161 as much $\mathrm{Hg}$ after 28 days as initially, and Z. mays about 60 times. The first plant accumulated on

162 average over this period $0.07 \mathrm{ng} \mathrm{Hg} \mathrm{mg}^{-1}$ per day, and the second plant $0.10 \mathrm{ng} \mathrm{Hg} \mathrm{mg}^{-1}$ day $^{-1}$.

163 These figures are consistent with those reported for Triticum durum (wheat) exposed to $5000 \mathrm{ng}$

$164 \mathrm{~m}^{-3} \mathrm{Hg}^{0}{ }^{0}{ }^{65}$ Foliar $\mathrm{Hg}$ concentration was $0.02 \mathrm{ng} \mathrm{mg}^{-1}$ before exposure, $0.39 \mathrm{ng} \mathrm{mg}^{-1}$ after $12 \mathrm{~h}, 1.90$

$165 \mathrm{ng} \mathrm{mg}^{-1}$ after 7 days, and $4.95 \mathrm{ng} \mathrm{mg}^{-1}$ after 15 days. Mercury levels were approximately 100 times

166 higher after 7 days and 250 times higher after 15 days than at the beginning of the experiment. The

167 average daily loading was $0.32 \mathrm{ng} \mathrm{Hg} \mathrm{mg}^{-1}$ day $^{-1}$. After correcting for the difference in $\mathrm{Hg}_{\mathrm{g}}^{0}$

168 concentration in the previous and current experiments, and taking a factor of $5000 / 1250=4$, the

169 renormalized daily accumulation of $\mathrm{Hg}$ in the $T$. durum experiment was $0.32 / 4=0.08 \mathrm{ng} \mathrm{Hg} \mathrm{mg}^{-}$

$170{ }^{1}$ day $^{-1}$. This accumulation rate falls within the range of the P. vittata and Z. mays rates. We must

171 therefore consider the plant's vegetative development. This effect, compounded by interspecific

172 physiological differences and changes in environmental factors, can explain the variability in $\mathrm{Hg}$

173 concentration observed in wild plants from the same species and the lack of discernible trends in

174 the 22 leaf tissues (Figure 1a). We can dismiss a soil effect because ${ }^{198} \mathrm{Hg}$ isotopic measurements

175 showed that inorganic mercury contained in roots is marginally translocated to aerial parts. ${ }^{66}$ 
Mercury speciation in ore and soils. The $\mathrm{Hg}$ ore and the Soil16 spectra were identified as

177 being from pure $\mathrm{Hg}$ species (Figures $2 \mathrm{a}$ and $2 \mathrm{~b}$ ). The ore spectrum has a highly structured pattern 178 in the top-edge region, characteristic of $\mathrm{Hg}-\mathrm{Hg}$ pairs from a well-crystallized mineral. Good 179 spectral match was obtained with cinnabar $(\alpha-\mathrm{HgS})$ (fit residual, NSS $\left.=6.1 \times 10^{-5}\right)$. The Soil16 180 spectrum also has modulations in the top-edge region, but with lower amplitudes, either because 181 there are fewer $\mathrm{Hg}-\mathrm{Hg}$ pairs (smaller grain size) or because the $\mathrm{Hg}-\mathrm{Hg}$ distances are unequal 182 (structural disorder). The best shape that best matched the reference database was obtained for 183 nanoparticulate metacinnabar $\left(\beta-\mathrm{HgS} \mathrm{SP}^{47}\right)\left(\mathrm{NSS}=8.4 \times 10^{-5}\right)$. Soil44 and Soil88 are intermediate 184 between $\mathrm{Hg}$ ore and Soil16, indicating that $\mathrm{Hg}(\mathrm{II})$ must be present as a combination of $\alpha-\mathrm{HgS}$ and $\beta-\mathrm{HgSNP}_{\mathrm{NP}}$ (Figure 3a). Soil88 is well described by a mixture of $45 \% \pm 7 \% \alpha-\mathrm{HgS}$ and $55 \pm 8 \% \beta-$ $186 \mathrm{HgS}_{\mathrm{NP}}\left(\mathrm{NSS}=4.6 \times 10^{-5}\right.$, Figure $3 \mathrm{~b}$ and SI Table S3). The precision of a $\mathrm{HgS}$ species percentage was estimated to be equal to the variation of its best-fit value obtained for an increase of $30 \%$ of the optimal NSS value (see details in the Data analysis section and SI Table S3). The best fit to the

189 Soil44 spectrum is obtained with $17 \% \pm 10 \% \alpha-\mathrm{HgS}+33 \% \pm 28 \%$ well-crystallized $\beta-\mathrm{HgS}+55 \%$ $190 \pm 22 \% \beta-\mathrm{HgS}_{\mathrm{NP}}\left(\mathrm{NSS}=3.0 \times 10^{-5}\right.$, Figure $3 \mathrm{~d}$ and SI Figure S1a). A two-component fit of Soil44 191 yields $26 \% \pm 7 \% \alpha-\mathrm{HgS}+73 \pm 8 \% \beta-\mathrm{HgSS}_{\mathrm{NP}}\left(\mathrm{NSS}=4.5 \times 10^{-5}\right.$, Figure $\left.3 \mathrm{c}\right)$. Owing to the nature 192 of the least-squares fitting, NSS is almost always smaller for a three-component fit than for a two193 component fit simply due to the increase in the number of variable parameters with three 194 components. Here, inclusion of well-crystallized $\beta-\mathrm{HgS}$ provides a better description of the data, 195 but obviously at the expense of the precision on each component species. Soil107 has a two196 component fit residual higher than the other soils (NSS $=14.2 \times 10^{-5}$ ). The quality of fit is clearly 197 not good (Figure 3e), so we attempted a three-component fit to the database spectra. Adding 9\% 198 elemental $\mathrm{Hg}\left(\mathrm{Hg}^{0}\right.$ s) decreases NSS by $24 \%\left(\mathrm{NSS}=10.8 \times 10^{-5}\right)($ Figure $3 \mathrm{f})$. Therefore, it is at least 199 plausible that $\mathrm{Hg}^{0}$ s adds something significant to the reconstruction. The sensitivity to this reference 200 is good, however, because the $\mathrm{Hg}^{0}{ }_{\mathrm{s}} \mathrm{HR}-\mathrm{XANES}$ spectrum is extremely structured at liquid helium 201 temperature (SI Figure 1b), in contrast to previous observation. ${ }^{67}$ 
Organically-bound mercury was tested with $\mathrm{Hg}(\mathrm{II})$ reacted for 15 hours with the Elliott Soil

203 humic acid [International Humic Substances Society (IHSS), catalog no. 1S102H]. This reference

204 features a dithiolate complex $\left(\mathrm{Hg}(\mathrm{SR})_{2}\right)$ in which $\mathrm{Hg}(\mathrm{II})$ is linearly coordinated to two proximal

$205 \mathrm{SR}^{-}$thiolates and to distant SRS thioethers $\left(2+k\right.$ coordination). ${ }^{47,53} \mathrm{The} \mathrm{Hg}(\mathrm{SR})_{2}$ complex is typical

206 of the form of $\mathrm{Hg}(\mathrm{II})$ in soil organic matter. ${ }^{68,} 69$ The linear RS-Hg-SR coordination produces, at

207 high energy-resolution, a sharp absorption feature at $12279 \mathrm{eV}$ not observed in the soil spectra (SI

208 Figure S2). Linear least-squares combination fits of the soil spectra show that this species makes

209 up at most 13\% of total Hg (SI Figure S2). Soluble Hg-containing phases, previously described in

210 gold mine tailings, ${ }^{70}$ are incompatible models with detection limits of $7 \%$ for the model compound

$211 \mathrm{HgCl}_{2}$ and $3 \%$ for $\left[\mathrm{Hg}\left(\mathrm{H}_{2} \mathrm{O}\right)_{6}\right]^{2+}$ (SI Figure $\left.\mathrm{S} 2\right)$.

212 Nano $\beta-\mathrm{HgS}$ is the dominant phase in all soils. It is unlikely to result from the transformation of

$213 \alpha-\mathrm{HgS}$ dust particles because the $\alpha$ allotrope is the thermodynamically stable mercury sulfide form

214 at ambient conditions. Metacinnabar is metastable and transforms over time into $\alpha-\mathrm{HgS}$ in the

215 absence of impurities. ${ }^{71-73}$ In 2016, we verified this by re-measuring the HR-XANES spectrum of

216 a pure $\beta-\mathrm{HgS}$ reference synthesized and measured in $2014^{47}$ (SI Figure S3). The $\beta$-HgS $\mathrm{NP}$ mercury

217 species may result from the deposition and oxidation of $\mathrm{Hg}^{0}$ g followed by the formation of a

$218 \mathrm{Hg}(\mathrm{SR})_{2}$ complex with soil organic matter and its subsequent transformation into $\beta-\mathrm{HgS} \mathrm{NP}^{47,57}$

219 Mercury speciation in foliage. Principal component analysis (PCA) of the 22 native plants and 220 the two plants exposed for 28 days to gaseous mercury in a growth chamber (corn C3 and P. vittata 221 Pv2) shows that three abstract components are required to account for the variance in the dataset 222 (SI Figure S4). Looking closely at the data and surveying the reference spectra, we found that two 223 component species are present in a single form in the leaf spectra: one (Sp1) in Desmodium sequax 224 Wall (Ds4) and corn (C3) leaves (Figures $1 \mathrm{~b}$ and 4a), and a second (Sp2) in four P. vittata leaves 225 (Pv14, Pv19, Pv25, Pv31). The Sp1 spectrum has HR-XANES features that most closely match the 226 reference spectra for $\mathrm{Hg}-(\mathrm{Cysteine})_{2}$ (abbreviated as $\left.\mathrm{Hg}(\mathrm{Cys})_{2}\right), \mathrm{Hg}$-(Glutathione) $)_{2}$ (abbreviated as $227 \mathrm{Hg}(\mathrm{GSH})_{2}$ ), and $\mathrm{Hg}$-Phytochelatin (abbreviated as $\mathrm{Hg}-\mathrm{PC} 2$ ) complex, in which $\mathrm{Hg}(\mathrm{II})$ is bonded 
almost linearly to two cysteinyl sulfur atoms (thiolate $\mathrm{SR}^{-}$ligand) and laterally to one or two

229 secondary nitrogen or oxygen atoms $\left(\mathrm{Hg}\left[(\mathrm{SR})_{2}+(\mathrm{N} / \mathrm{O})_{1-2}\right]\right.$ coordination) (Figures $4 \mathrm{~b}$ and $4 \mathrm{~d}$, SI

230 Figures S5, S6, S7, and S8). Recently described primary coordination to nitrogen atoms ${ }^{74}$ was $^{2}$

231 evaluated with the $\mathrm{Hg}$ (Histidine)2 complex. This ligand gives distinctive HR-XANES signal (SI

232 Figure S9). The Sp2 spectrum shows a distinct signature on the second absorption peak at circa

$233 \quad 12288.5 \mathrm{eV}$ (Figure 4a): its amplitude is enhanced as observed when $\mathrm{Hg}$ is bonded linearly to aryl

234 thiolate ligands (SI Figure S10). Linear coordination was expected in leaf tissues because it is the most common geometry in mercury chemistry and it occurs in biological systems in complexes with cysteine, peptides, and proteins. ${ }^{46,75-84}$

237 The third spectral component is a combination of Sp1/Sp2 and $\beta$-HgS $\mathrm{NP}$ (Figures $4 \mathrm{a}$ and $4 \mathrm{c}$ ).

238 Nano $\beta-\mathrm{HgS}$ is manifested in the trailing spectral region of Figure $4 \mathrm{a}$ as a shift to the left, similarly

239 to the soil spectra (Figure 3a). This shift signifies longer Hg-ligand distances, and is observed 240 typically when $\mathrm{Hg}$ is tetrahedrally coordinated to sulfur atoms as in $\beta-\mathrm{HgS}^{46}$. A polynuclear 241 tetracysteinate complex $\left(\mathrm{Hg}_{\mathrm{x}}(\mathrm{Cys})_{\mathrm{y}}\right)$ of the type existing in metalloproteins, represented here by a 242 metallothionein isolate from Mytilus edulis (MT2), is an incompatible model (Figure 5 and 243 Discussion).

244 We identified mercury-sulfur $\mathrm{Hg}_{\mathrm{x}} \mathrm{S}_{\mathrm{y}}$ clusters with a $\beta$-HgS $\mathrm{S}_{\mathrm{NP}}$-type structure in 15 leaf samples 245 from six plant species, and in amounts ranging from $12 \%$ to $57 \% \pm 8 \%$ (Figure $1 \mathrm{~b}$ and SI Table $246 \mathrm{~S} 1$ ). Since total $\mathrm{Hg}$ concentration in leaves is between 2 and $30 \mathrm{ppm}$, and the two $\mathrm{HgS}$ NP richest 247 plants (55\% $\mathrm{HgS}_{\mathrm{NP}}$ in $\mathrm{Vn} 6$ and 57\% in Po2) have only $1.9 \mathrm{ppm}(\mathrm{Po} 2)$ and $5.6 \mathrm{ppm}(\mathrm{Vn} 6) \mathrm{Hg}$ in the 248 form of $\beta-\mathrm{Hg}_{\mathrm{SN}}$, the amount of this species is too vanishingly small to be observed by electron 249 microscopy even with a cutting-edge instrument. The multinuclear $\mathrm{Hg}_{\mathrm{x}} \mathrm{S}_{\mathrm{y}}$ species always coexists 250 with at least one of the two linear forms $\mathrm{Sp} 1$ and $\mathrm{Sp} 2$. In contrast to $\mathrm{Hg}_{\mathrm{x}} \mathrm{S}_{\mathrm{y}}, \mathrm{Sp} 1$ and $\mathrm{Sp} 2$ can occur 251 in pure form. Four wild P. vittata plants out of eight total contain only Sp2 (Pv14, Pv19, Pv25, 252 Pv31, Figure 1b). After 28 days exposure to $\mathrm{Hg}_{\mathrm{g}}^{0}$, greenhouse $\mathrm{C} 3$ contains only Sp1, like the wild 253 Ds4 plant, and greenhouse Pv2 has both Sp1 and Sp2, like the wild Pv8 plant. The high consistency 
between speciation results obtained ex situ on artificially exposed plants and on native plants supports our experimental approach and suggests that the $\beta$-HgS $\mathrm{S}_{\mathrm{NP}}$-type species is a secondary species that appears after some period of time. Field-grown leaves were much older than 28 days as they were sampled at the end of the florishing season on September 30 and October 15, 2015.

258 For example, the green foliage of Pteris vittata appears in April and was therefore five-month old when collected in October. The leaves from Vitex negundo were even older because this shrud is semi-evergreen, shedding foliage and producing new foliage almost simultaneously in DecemberApril. Longer exposure to gaseous elemental mercury also led to higher mercury concentration in

262 leaf, ${ }^{61}$ despite the lower vapor $\mathrm{Hg}$ concentration in the field relative to that in the growth chamber 263 (Table S1). When comparing $\mathrm{Hg}$ speciation between field-grown and chamber-grown leaf, one needs to consider that $\beta-\mathrm{HgS}_{\mathrm{NP}}$ takes typically at least a week to nucleate and start growing. ${ }^{47}$ This secondary species is difficult to detect in a growth experiment when the plant is continuously exposed to $\mathrm{Hg}^{0}$. To detect fresly formed $\beta-\mathrm{HgS}_{\mathrm{NP}}$, one would need to stop evaporating $\mathrm{Hg}$ in the gas chamber to let the new added $\mathrm{Hg}$ atoms react with reduced sulfur.

\section{DISCUSSION}

270 A highlight of this study is the detection of mercury-sulfur clusters in leaves impacted by 271 atmospheric contact with gaseous mercury. The origin and nature of the $\mathrm{Hg}_{\mathrm{x}} \mathrm{S}_{\mathrm{y}}$ clusters can be 272 apprised from their structure. Three hypotheses are examined below: (1) mercury sulfide grains 273 from dust particles, (2) mercury-cysteinate clusters, and (3) cysteinate-protected mercury sulfide 274 nanoparticles.

275 Mercury sulfide dust particles. If the $\mathrm{Hg}_{\mathrm{x}} \mathrm{S}_{\mathrm{y}}$ clusters were acquired from dust fallout, one 276 would expect the $\beta-H g S_{N P}$ particles to be associated with $\alpha-\mathrm{HgS}$ particles from the nearby mercury 277 mines. With typical length of $20-30 \mu \mathrm{m}$ and width of $10-20 \mu \mathrm{m},{ }^{85,86}$ epidermal stomatal pores could 278 allow the finest $\alpha-\mathrm{HgS}$ grains to enter the leaf tissues. However, gravity would limit this contamination pathway because stomata are more numerous on the abaxial (hypostomatic) than on 
the adaxial (epistomatic) leaf surface for most plant species ${ }^{85}$ Here, at least two plants containing

$281 \mathrm{Hg}_{\mathrm{x}} \mathrm{S}_{\mathrm{y}}$ are known to be hypostomatous, P. vittata and Juglans regia. ${ }^{85,}{ }^{86}$ Mineral particles on the

282

283 upper leaf surface can also be dismissed because the leaves were carefully washed with purified water. Actually, an $\alpha-\mathrm{HgS}$ particle was detected in one spot of Vitex negundo (Vn30) out of 108 spots measured for this plant (Figure 6). No $\alpha-\mathrm{HgS}$ particles were detected in the 21 other wild plants, representing a total of $21 \times 108=22268$ points measured by HR-XANES. We conclude from this that the $\beta-H g S_{N P}-t y p e$ species has an endogenous origin.

Mercury-cysteinate clusters. A second possibility is the binding of $\mathrm{Hg}$ (II) to multi-metal binding sites of metalloproteins, such as metallothioneins (MTs). Metallothioneins are small cysteine-rich proteins considered to be involved in the homeostasis of essential metal ions (i.e., $\mathrm{Zn}(\mathrm{II})$ and $\mathrm{Cu}(\mathrm{I})$ ), to confer metal resistance (e.g., $\mathrm{Cd}(\mathrm{II})$ and $\mathrm{Hg}(\mathrm{II})$ ), and to scavenge cell damaging reactive oxygen species (ROS). ${ }^{87-89}$ Stomata guard cells, which regulate gas exchange $\left(\mathrm{CO}_{2}, \mathrm{O}_{2}, \mathrm{H}_{2} \mathrm{O}, \mathrm{Hg}^{0}\right)$, contain numerous proteins harboring cysteine residues and conveying environmental signaling. ${ }^{87,90,91}$

Divalent $\mathrm{Zn}$ and $\mathrm{Cd}$ (hereafter referred to as $\mathrm{Me}^{\mathrm{II}}$ ) are bound to MTs mainly as tetracysteinate complex to terminal $(\mu-S R)$ and bridging $\left(\mu_{2}-\mathrm{SR}\right)$ cysteinyl sulfur ligands. Mononuclear $\mathrm{Me}^{\mathrm{II}}\left(\mathrm{Cys}_{2} \mathrm{His}_{2}\right)$ complexes, ${ }^{88,92}$ and homometallic dinuclear $\mathrm{Me}_{2}{ }_{2} \mathrm{Cys} 6,{ }^{93}, 94$ trinuclear $\mathrm{Me}^{\mathrm{II}}{ }_{3} \mathrm{Cys} 9,{ }^{88}$, 92 and tetranuclear clusters are known in plants ${ }^{95,96}$ (Figure 7). The structures of the three- and fourmetal clusters are described below. The trinuclear plant cluster is isostructural to the $\mathrm{Me}^{\mathrm{II}}{ }_{3} \mathrm{Cys} 9$ cluster from the $\beta$ domain of animal MTs, although plant and animal MTs differ in the number and distribution pattern of the Cys residues in the amino-acid sequence. ${ }^{97-99}$ The three $\mathrm{Me}^{\mathrm{II}}(\mathrm{Cys})_{4}$ tetrahedra from the structurally conserved $\mathrm{Me}_{3}{ }_{3} \mathrm{Cys} 9$ cluster are connected by apices via three cysteinyl sulfurs which each bridges only two Me atoms ( $\mu_{2}-\mathrm{SR}$ sulfur atoms) (Figure 7a). The same polyhedral connectivity exists in $\beta-\mathrm{HgS}$, except that all bulk sulfur atoms are of the $\mu_{4}-\mathrm{S}$ type (insert in Figures $2 b$ and $7 b$ ).

A $\mathrm{Me}_{4}{ }_{4}{ }_{4}$ ys $10 H i s$ amino acid composition was inferred for the Musa acuminata (banana) 
tetranuclear cluster (Figure 7g). ${ }^{95}$ It resembles the common $\mathrm{Me}^{\mathrm{II}}{ }_{4} \mathrm{Cys}_{11}$ cluster from the $\alpha$ domain

307 of animal MTs ${ }^{97}$ with a Cys residue replaced by an histidine residue (Figure $7 \mathrm{c}$ ), ${ }^{95}$ and also the

$308 \mathrm{Me}^{\mathrm{II}}{ }_{4} \mathrm{Cys}_{9} \mathrm{His}_{2}$ cluster in a cyanobacterial $\mathrm{MT}^{100}$ with one of the two His residues replaced by one

309 Cys residue. The $\mathrm{Me}^{\mathrm{II}}{ }_{4} \mathrm{Cys}_{11}-\alpha$ cluster arrangement is obtained by bonding a fourth tetracysteinate

310 to two terminal $\mu_{1}-\mathrm{SR}$ sulfurs from a $\mathrm{Me}_{3}^{\mathrm{II}_{3} \mathrm{Cys}-}-\beta$ cluster. The Mytilus edulis $\mathrm{MT}$ reference (MT2)

311 used in this study has a prototypical $\mathrm{Me}^{\mathrm{II}}{ }_{3} \mathrm{Cys} 9-\beta$ site and a $\mathrm{Me}^{\mathrm{II}}$-binding $\alpha$ site that differs little

312 from the $\mathrm{Me}^{\mathrm{II}}{ }_{4} \mathrm{Cys} 11-\alpha$ site. The $\alpha$ cluster arrangement in $M$. edulis is obtained by attaching a fourth

313 tetracysteinate to a $\beta$-type $\mathrm{Me}^{\mathrm{II}}{ }_{3}$ Cys 9 cluster by a single $\mu_{1}-\mathrm{SR}$ sulfur ${ }^{101}$ (Figure $7 \mathrm{e}$ ). Consequently,

314 the stoichiometry of the Mytilidae $\alpha$ site is $\mathrm{Me}^{\mathrm{II}}{ }_{4} \mathrm{Cys} 12$ instead of $\mathrm{Me}^{\mathrm{II}}{ }_{4} \mathrm{Cys}_{11}$, common in animals.

315 The $\left\{\mathrm{Me}_{4}{ }_{4} \mathrm{Cys}_{12}\right\}$ core of $\mathrm{Me}^{\mathrm{II}}{ }_{4} \mathrm{Cys} 12-\alpha$ can be represented as a portion of the $\beta$-HgS lattice, like 316 the $\left\{\mathrm{Me}_{3} \mathrm{~S}_{9}\right\}$ core of $\mathrm{Me}_{3}^{\mathrm{II}}{ }_{3} \mathrm{Cys} 9-\beta$ (Figures $7 \mathrm{e}$ and $7 \mathrm{f}$ ). However, the $\left\{\mathrm{Me}_{4} \mathrm{~S}_{11}\right\}$ core of $\mathrm{Me}_{4} \mathrm{Cys}_{11^{-}}$

$317 \alpha$ cannot (Figures 7c and 7d). In a tetranuclear $\beta$-HgS-type cluster each tetrahedron shares three

318 sulfurs yielding an adamantane-type cage (Figure 7d). In $\mathrm{Me}_{4}{ }_{4} \mathrm{Cys}_{11}-\alpha$, only two tetrahedra have

319 three bridging sulfurs and the two other have two bridging sulfurs (Figure 7c).

320 Lastly, a cluster with nuclearity five $\left(\mathrm{Hg}_{5} \mathrm{Cys} 12\right)$ has been suggested in Cicer arietinum 321 (chickpea) MT, based on $\mathrm{Hg}$ :Cys stoichiometric considerations. ${ }^{102}$ The $\mathrm{Hg}_{5} \mathrm{Cys} 12$ model consists 322 of two dinuclear complexes of $\mathrm{Me}^{\mathrm{II}}{ }_{2} \mathrm{Cys}_{6}-{ }_{-t y p e}{ }^{93,94}$ linked by a fifth $\mathrm{Hg}(\mathrm{II})$ ion (Figure $7 \mathrm{~h}$ ). This 323 assemblage features $\left\{\mathrm{HgS}_{4}\right\}$ tetrahedra linked by edges, not by apices as in all structurally known $324 \mathrm{Me}^{\mathrm{II}}$-MT clusters and observed here by HR-XANES. In addition, edge-linkage in complexes

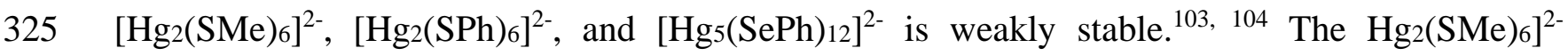
326 complex was shown by Raman spectroscopy to dissociate in solution into mononuclear $327\left[\mathrm{Hg}(\mathrm{SMe})_{3}\right]^{-}$ions. ${ }^{105}$

328 HR-XANES results show that the $\beta-\mathrm{HgS}_{\mathrm{NP}}$ reference is a much better structure model to the 329 multinuclear $\mathrm{Hg}_{\mathrm{x}} \mathrm{S}_{\mathrm{y}}$ foliar species than the MT2 mussel reference, despite the similarity of the $330\left\{\mathrm{HgS}_{4}\right\}$ tetrahedral arrangements in the two references (Figure 7). To gain further insight into the 331 reason for the suitability of the $\beta-H g S_{N P}$ model and incompatibility of the MT2 model, the 
structures of $\mathrm{Hg}_{3} \mathrm{Cys} 9, \mathrm{Hg}_{4} \mathrm{Cys}_{11}, \mathrm{Hg}_{4} \mathrm{Cys}_{12}$, and $\mathrm{Hg}_{4} \mathrm{Cys}_{10} \mathrm{His}$ were optimized geometrically and compared to the polyhedral $\beta-\mathrm{HgS}$ structure. Cysteine was replaced by the model thiolate ligand methanethiolate $\left(\mathrm{CH}_{3} \mathrm{~S}^{-}\right)$, as in our previous computational studies. ${ }^{46,47,52,53,57,106}$ This substitution does not change, or only marginally changes, the $\mathrm{Hg}-\mathrm{S}$ bond length, the geometry of the complex, and the effective atomic charge on the sulfur (-0.63 e vs. -0.65 e) and $\mathrm{Hg}(+1.18$ e vs. +1.16 e $)$ atoms (SI Figure S11). However, the predicted $\mathrm{Hg}-\mathrm{Hg}$ distances and geometry will be somewhat affected in MTs by the enfolding protein backbone structure. This effect was not taken into account in the modeling. The energy-minimized models are shown in Figure 7. The calculated Hg-S distances of the four $\operatorname{Hg}_{\mathrm{x}}(\mathrm{Cys})_{\mathrm{y}}$ clusters are identical $(2.52 \pm 0.06-0.08 \AA)$ and close to 341 crystallographic values for inorganic $\operatorname{Hg}(\mathrm{SR})_{4}$ complexes $(2.566 \pm 0.047 \AA)^{107}$ and wellcrystallized $\beta-\mathrm{HgS}\left(2.53 \AA^{108}\right)$. The nearest $\mathrm{Hg}$ shell distance $\left(d\left(\mathrm{Hg}-\mathrm{Hg}_{1}\right)\right)$ in $\mathrm{Hg}_{4} \mathrm{~S}_{11}(4.13 \pm 0.19$ $\AA)$ and $\mathrm{Hg}_{4} \mathrm{~S}_{10} \mathrm{His}(4.07 \pm 0.20 \AA)$ coincides with that in $\beta-\mathrm{HgS}(4.14 \AA)$, whereas it is significantly longer in the two other clusters $(4.43 \pm 0.05-0.10 \AA)$. The calculated $\mathrm{Hg}-\mathrm{N}$ bond length in $\mathrm{Hg}_{4} \mathrm{~S}_{10} \mathrm{His}$ is about $0.2 \AA$ shorter than the $\mathrm{Hg}$-S distance and the geometry of the $\left\{\mathrm{HgS}_{3} \mathrm{~N}\right\}$ site is trigonal pyramidal with $\mathrm{S}-\mathrm{Hg}-\mathrm{N}$ angles of $101.7^{\circ} \pm 8.0^{\circ}$ and $\mathrm{S}-\mathrm{Hg}-\mathrm{S}$ angles of $116.0^{\circ} \pm 7.4^{\circ}$, compared to the canonic $109.5^{\circ}$ bond angles in a regular $\left\{\mathrm{HgS}_{4}\right\}$ tetrahedron (SI Figure S12). Overall, the $\mathrm{Hg}_{\mathrm{x}}(\mathrm{Cys})_{\mathrm{y}}$ clusters have local structures close or broadly similar to $\beta-\mathrm{HgS}$. In this respect, both the $\beta-\mathrm{HgS}_{\mathrm{NP}}$ and MT2 references can be regarded as computationally tractable analogues for modeling the $\mathrm{Hg}_{\mathrm{x}} \mathrm{S}_{\mathrm{y}}$ clusters in leaves. Because it is not the result of a difference in coordination mode, we need to explain that the $\beta-\mathrm{HgS}_{\mathrm{NP}}$ model is fit and the MT2 model unfit.

The sulfide $\beta-\mathrm{HgS}_{\mathrm{NP}}$ and cysteinate MT2 models differ in two complementary ways. One is greater variation in the calculated $\mathrm{Hg}-\mathrm{Hg}$ distances in MT clusters, being more pronounced with

354 four $( \pm 0.10-0.20 \AA)$ than three $( \pm 0.05 \AA)$ metals (Figure 7). A more significant reason is the cluster size: MT nanoclusters with nuclearity of only three to four are vanishingly small compared to nanosized $\beta$-HgS particles; MT2 lacks any $\mathrm{Hg}$-Hg pair beyond $7 \AA$. These two factors, structural disorder and reduced size, indistinguishably cause smearing of the HR-XANES features as a result 
of losing the multiple scattering events of the photoelectron on the $\mathrm{Hg}$ shells. This effect is clearly seen on the MT2 spectrum when it is superimposed on the spectra from the two leaf samples Po2 and Vn6 which have the highest proportion of the $\beta-\mathrm{HgS} \mathrm{S}_{\mathrm{NP}}$ component $(57 \%$ and $55 \%$, respectively, SI Table S1). The MT2 spectrum has a bell-shaped top edge with no modulation of

362 the absorption signal, whereas the two leaf spectra present oscillations from long distance $\mathrm{Hg}-\mathrm{Hg}$ pairs (Figure 4b). We attempted to determine the size of the $\mathrm{Hg}_{\mathrm{x}} \mathrm{S}_{\mathrm{y}}$ clusters in plant leaves.

The $\beta$-HgS $\mathrm{NP}$ reference was used previously to model the HR-XANES spectrum of $\sim 3-5 \mathrm{~nm} \beta-$ $\mathrm{HgS}$ nanocrystals in natural organic matter (NOM).${ }^{47}$ The mercury sulfide clusters in NOM evolved from $\mathrm{Hg}(\mathrm{SR})_{2}$ complexes under aerated conditions within days to weeks at mercury concentrations of several hundred ppm down to three ppm. We examined whether one of the leaf spectra could be matched with an aged Hg-NOM spectrum. Good qualitative agreement was obtained between $V$.

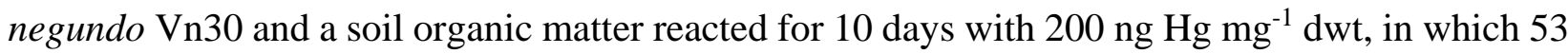
$\pm 6 \mathrm{~mol} \%$ of the $\mathrm{Hg}$ is speciated as $\mathrm{Hg}(\mathrm{SR})_{2}$ and $47 \pm 6 \mathrm{~mol} \%$ as $\beta-\mathrm{HgS}_{\mathrm{NP}}\left(\mathrm{NSS}=6.6 \times 10^{-5}\right.$, Figure 8a). This match suggests some degree of similarity between the nanoclusters in Hg-NOM and in foliar tissues, but gives us little information on their respective size, as explained below.

Lattice plane spacings corresponding to those of $\beta-\mathrm{HgS}$ have been imaged previously in single 3-5 $\mathrm{nm}$ nanocrystals from the $\mathrm{Hg}-\mathrm{NOM}$ with high-resolution transmission electron microscopy (HRTEM) (insert Figure 8a). ${ }^{47}$ However, the nanocrystallized grains imaged by HRTEM likely contain structural defects and, consequently, have a crystal domain size (i.e., "crystallinity") lower 377 than their macroscopic grain size of $\sim 3-5 \mathrm{~nm}$. In contrast to HRTEM, X-ray absorption 378 spectroscopy (XAS) is sensitive to the structural environment of all selectively excited atoms (here $379 \mathrm{Hg}$ ), including those located within a domain, in domain boundaries, and at the grain surface. 380 Mercury atoms exposed at the surface and in the interstices of crystal domains have fewer $\mathrm{Hg}-\mathrm{Hg}$ 381 pairs and unequal bond lengths relative to those in the inside. Thus, XAS cannot distinguish large 382 disordered nanoclusters of $\sim 3-5 \mathrm{~nm}$ from smaller, less distorted clusters. ${ }^{109}$ HR-XANES's lack of 383 sensitivity to cluster size is compounded if all the nanoparticles are not identical in size, shape, and 
chemical composition, which is generally the case in natural materials. The $1 \mathrm{~nm}\left\{\beta-\mathrm{Hg}_{7} \mathrm{~S}_{16}\right\}$ cluster represented in Figure $8 \mathrm{~b}$ provides a sense of the reduction of the $\mathrm{Hg}-\mathrm{Hg}$ coordination in a nanometer-sized $\beta$-HgS particle. The $\mathrm{Hg}-\mathrm{Hg}$ coordination number is 4 in the first-shell (4.14 $\mathrm{A})$,

3870.6 in the second $(5.85 \AA), 1.1$ in the third $(7.17 \AA)$, and 0.3 in the fourth $(8.28 \AA)$, compared to $38812,6,24$, and 12, respectively, for an infinite lattice. Based on XANES calculations, ${ }^{110,}{ }^{111}$ we 389 estimate that the leaf clusters have at least this average size.

390 From these considerations the finding emerges that the $\operatorname{Hg}_{\mathrm{x}} \mathrm{S}_{\mathrm{y}}$ clusters from the plant leaves are 391 relatively big, probably several nanometers in size as observed for gold and silver nanoparticles in 392 Medicago sativa (alfalfa) and copper in wetlands plants. ${ }^{112-116}$ The maximum $\mathrm{Hg}$ binding capacity 393 of MTs depends on the number of Cys residues. This number is extremely variable in plants, 394 ranging from typically ten to 17 per MT molecule. ${ }^{98}$ Assuming that the plant MTs have enough 395 structural plasticity to bring the Cys-rich regions into proximity for large cluster formation, ${ }^{99,117}$ 396 the number of $\mathrm{Hg}$ atoms within a $\beta$-HgS-type MT cluster is at most seven, for a total of $16 \mathrm{Cys}$ 397 residues (Figure 8b). Based on the $\beta-\mathrm{HgS}$ structure, at least two additional Cys residues will be 398 required to incorporate an eighth $\mathrm{Hg}$ atom, bringing the total number of Cys residues to 18. This 399 number exceeds the binding capacity of a single plant's MT molecule. Intermolecular Cys-Hg-Cys 400 bonding with exogenous Cys residues cannot be excluded in principle because dimeric forms of 401 MTs exist in animals. In Mytilidae, MT dimers are transcriptionally induced from DNA following 402 specific exposure to $\mathrm{Cd}(\mathrm{II})$, not to $\mathrm{Zn}(\mathrm{II})$ nor $\mathrm{Cu}(\mathrm{I})$, and are enriched in $\mathrm{Cd}$ relative to the 403 monomeric form. ${ }^{118-123}$ We conclude from this that the $\beta$-HgS $\mathrm{NP}_{\mathrm{N}}$-type structure identified by HR404 XANES could be a mercury-cysteinate cluster of approximate stoichiometry $\mathrm{Hg}_{7} \mathrm{Cys} 16$.

405 Mixed sulfide-cysteinate mercury clusters. A third structural possibility is a mixed $\mathrm{Hg}$ sulfide 406 and $\mathrm{Hg}$ cysteinate cluster, made of a sulfide mineral core and outer cysteine residues from an 407 encapsulating protein, as known in organometallic compounds and $\mathrm{Fe}_{\mathrm{x}} \mathrm{S}_{\mathrm{y}}$ metalloenzymes. ${ }^{124-129}$ In 408 the iron-storage ferritin protein, metalloclusters in the inner cage surface serve as putative 409 nucleation sites that facilitate the subsequent growth of a mineral core. ${ }^{130-132}$ Formation of 
polymetallic $\mathrm{Hg}(\mathrm{II})$ species from $\mathrm{Hg}(\mathrm{SR})_{2}$ thiolate complexes with concomitant loss of the peptide

411 structure has been reported in de novo peptide mimicking the chelating properties of 412 metalloproteins. ${ }^{133}$ Thiolate complexes with $\mathrm{d}^{10}$ metals, such as $5 \mathrm{~d}^{10} \mathrm{Au}(\mathrm{I})$ and $4 \mathrm{~d}^{10} \mathrm{Ag}(\mathrm{I})$, are 413 common precursors in the (bio)synthesis of metal sulfide and metallic nanoparticles. Capping with 414 inorganic thiolate ligands or association with scaffolding Cys-rich proteins helps stabilize the 415 particles and control their size, shape and crystallinity. ${ }^{113}$, ${ }^{134-142}$ Furthermore, thermodynamic 416 calculation shows that the stability of $\operatorname{Hg}_{\mathrm{x}} \mathrm{S}_{\mathrm{y}}$ clusters increases with nuclearity. ${ }^{53}$ Metallophilic 417 attraction is explained at the atomistic level by relativistic effects. ${ }^{143,144}$

418 According to this scheme, the $\mathrm{Hg}$ sulfide core could be formed in vivo from the reaction of $419 \mathrm{Hg}(\mathrm{SR})_{2}$ peptide complex with hydrogen (mono)sulfide $\left(\mathrm{H}_{2} \mathrm{~S} / \mathrm{HS}^{-}\right)$generated enzymatically by L420 Cys desulfhydrase. ${ }^{145-147}$ This enzyme enhances Arabidopsis tolerance to Cd(II) stress through the 421 catalytic desulfuration of L-Cys and induction of MTs genes expression. ${ }^{148}$ Biogenesis of $\mathrm{Hg}$ 422 sulfide clusters could also occur via a reaction analogous to the production of Fe-S clusters in 423 Arabidopsis. ${ }^{149}$ Sulfur is provided by a cysteine desulfurase which releases $S$ from Cys that 424 subsequently becomes incorporated during Fe-S cluster synthesis. Lastly, sulfide sulfur could also 425 be produced chemically by a dealkylation reaction between two $\mathrm{Hg}(\mathrm{SR})_{2}$ complexes. ${ }^{47,}{ }^{57}$ This 426 reaction can be written:

$$
\mathrm{RS}-\mathrm{Hg}-\mathrm{SR}+\mathrm{RS}-\mathrm{Hg}-\mathrm{SR} \rightarrow \mathrm{RS}-\mathrm{Hg}-\mathrm{S}-\mathrm{Hg}-\mathrm{SR}+\mathrm{R}-\mathrm{S}-\mathrm{R}
$$

428 The 1:1 molar ratio of $\mathrm{S}$ to $\mathrm{Hg}$ in the growing $\mathrm{HgS}$ core, compared to 2:1 initially in $\mathrm{Hg}(\mathrm{SR})_{2}$, is 429 obtained by replication of the previous nucleation reaction according to:

$$
\mathrm{RS}-\mathrm{Hg}-\mathrm{S}-\mathrm{Hg}-\mathrm{SR}+x(\mathrm{RS}-\mathrm{Hg}-\mathrm{SR}) \rightarrow \mathrm{RS}-(\mathrm{HgS})_{\mathrm{x}+2}-\mathrm{R}+x(\mathrm{R}-\mathrm{S}-\mathrm{R})
$$

432 atoms "see" each other, a likelihood which should normally increase with $\mathrm{Hg}$ concentration. 433 Actually, the leaf fraction of $\beta-\mathrm{HgS}_{\mathrm{NP}}$ does not correlate with the $\mathrm{Hg}$ content. Noteworthy is $P$

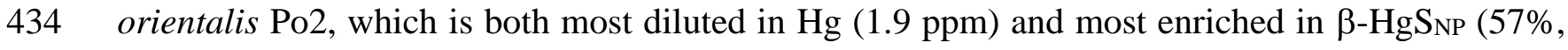
435 Figure $1 \mathrm{~b}$ and SI Table S1). Lack of correlation could plausibly be attributed to anatomical and 
physiological variability within and among species. For instance, the inflow of gaseous $\mathrm{Hg}$ is not

437 homogenous on the leaf surface but varies with the density of stomata, which is about $370-500 / \mathrm{mm}^{2}$ 438 for $V$. negundo, ${ }^{150}, 258 / \mathrm{mm}^{2}$ for $P$. vittata, ${ }^{86} 183-335 / \mathrm{mm}^{2}$ for $J$. regia, ${ }^{85}$ and below $100 / \mathrm{mm}^{2}$ for 439 corn. ${ }^{151}$ The bulk Hg concentration does not reflect how the mercury atoms are distributed at the 440 cell level because mercury is accumulated near the stomata. In NOM, $\beta-\mathrm{HgS} \mathrm{SP}_{\mathrm{NP}}$ was also observed 441 to nucleate at the somewhat low $\mathrm{Hg}$ concentration of $3 \mathrm{ppm}$ (Manceau et al., in preparation). In this 442 case, one main reason is the natural clustering of thiolate groups in compositionally heterogeneous 443 and polyfunctional macromolecular NOM. In biota, metalloproteins can sense metals and form 444 polynuclear clusters at extremely low concentrations. ${ }^{152}$ For instance, the regulatory protein MerR 445 encoded by the mer operon responds to nanomolar $\mathrm{Hg}(\mathrm{II})$ concentrations. ${ }^{153}$ MerR is also selective 446 and discriminates $\mathrm{Hg}(\mathrm{II})$ against other chemically similar $\mathrm{d}^{10}$ heavy metals, such as $\mathrm{Zn}$ (II), $\mathrm{Cd}(\mathrm{II})$, $447 \operatorname{Ag}(\mathrm{I})$, and $\mathrm{Au}(\mathrm{I})$, even at concentrations in these metals two to three orders of magnitude greater 448 than that required for $\mathrm{Hg}(\mathrm{II})$ detection. ${ }^{153}$

449 In summary, the results presented here show that aerial gaseous mercury taken up by leaf tissues 450 can be sequestered as divalent mercury-sulfur nanoparticles. This finding suggests interesting 451 hypotheses and also brings up challenging questions. For instance, is mercury partially 452 biomineralized in sulfide form, or is it clustered as mercury-cysteinate complexes in cysteine-rich 453 biomolecules? Is one of the two forms more stable than the other, therefore less toxic? May either 454 form be remobilized or revolatilized once deposited in litterfall, or are they recalcitrant to 455 biogeochemical transformation? To date, conversion of thiol-bound $\mathrm{Hg}$ (II) to nanoparticulate $\beta$ $456 \mathrm{HgS}$ under ambient atmospheric conditions has been documented in natural organic matter ${ }^{47}$ and 457 suggested to occur in contact with bacteria. ${ }^{147}$ These considerations, together with the close 458 similarity between the spectra from organic matter containing 3-5 $\mathrm{nm} \mathrm{HgS}$ nanocrystals and from 459 some of the leaf tissue is extremely strong support for the presence of $\mathrm{HgS}_{\mathrm{NP}}$ in the leaves. 460 Therefore, this new study provides another evidence for the widespread occurrence of $\beta-\mathrm{HgS} \mathrm{S}_{\mathrm{NP}}$ 461 under aerated conditions. Perhaps nanoparticulate metacinnabar, regardless of its biotic or abiotic 
462 origin, is a main source of the legacy mercury pool stored in soils..$^{58,154}$

463

464 ASSOCIATED CONTENT

465 Supporting Information is available free of charge

466 Detailed experimental accounts, Figures S1-S13, Tables S1-S3, Cartesian coordinates of the 467 optimized $\mathrm{Hg}_{\mathrm{x}} \mathrm{S}_{\mathrm{y}}$ clusters and $\mathrm{Hg}$ complexes, ascii data from a selection of HR-XANES spectra.

468

469 AUTHOR INFORMATION

470 Corresponding authors

$471 \quad$ alain.manceau@univ-grenoble-alpes.fr

472 fengxinbin@vip.skleg.cn

473

$474 \quad$ Notes

475 The authors declare no competing financial interest.

477 ACKNOWLEDGEMENTS

478 Support was provided to A.M by the French National Research Agency (ANR) under grant ANR479 12-BS06-0008-01, to A.M., M.R., and P.G. by the ANR under Grant ANR-10-EQPX-27-01 (EcoX 480 Equipex), to J.W and X.F by Chinese Academy of Sciences (QYZDJ-SSW-DQC005). The Froggy 481 platform of the CIMENT infrastructure (ANR Grant ANR-10-EQPX-29-01) provided computing 482 resources and Pierre Girard his expertise in parallel scientific processing. M. Lanson and A. Lannes 483 are thanked for the preparation of $\mathrm{Hg}$ complexes, and Paco Bustamante and Serge Pin for the 484 preparation of the metallothionein reference.

485

486 REFERENCES 
(1) Rea, A. W.; Keeler, G. J.; Scherbatskoy, T., The deposition of mercury in throughfall and 488 litterfall in the lake champlain watershed: A short-term study. Atmos. Environ. 1996, 30, 32573263.

490 (2) Rea, A. W.; Lindberg, S. E.; Scherbatskoy, T.; Keeler, G. J., Mercury accumulation in foliage 491 over time in two northern mixed-hardwood forests. Water Air Soil Poll. 2002, 133, 49-67.

492 (3) Biester, H.; Müller, G.; Schöler, H. F., Estimating distribution and retention of mercury in 493 three different soils contaminated by emissions from chlor-alkali plants: part I. Sci. Tot. Environ. 494 2002, 284, 177-189.

495 (4) Ericksen, J. A.; Gustin, M. S., Foliar exchange of mercury as a function of soil and air mercury 496 concentrations. Sci. Tot. Environ. 2004, 324, 271-279.

497 (5) Feng, X.; Qiu, G., Mercury pollution in Guizhou, Southwestern China - An overview Sci. Tot. 498 Environ. 2008, 400, 227-237.

499 (6) Meng, B.; Feng, X. B.; Qiu, G. L.; Cai, Y.; Wang, D. Y.; Li, P.; Shang, L. H.; Sommar, J., 500 Distribution patterns of inorganic mercury and methylmercury in tissues of rice (Oryza sativa L.) 501 plants and possible bioaccumulation pathways. J. Agr. Food Chem. 2010, 58, 4951-4958.

502 (7) Obrist, D.; Johnson, D. W.; Lindberg, S. E.; Luo, Y.; Hararuk, O.; Bracho, R.; Battles, J. J.; 503 Dail, D. B.; Edmonds, R. L.; Monson, R. K.; Ollinger, S. V.; Pallardy, S. G.; Pregitzer, K. S.; Todd, 504 D. E., Mercury distribution across 14 U.S. forests. Part I: Spatial patterns of concentrations in 505 biomass, litter, and soils. Environ. Sci. Technol. 2011, 45, 3974-3981.

506 (8) Wang, J. X.; Feng, X. B.; Anderson, C. W. N.; Zhu, W.; Yin, R. S.; Wang, H., Mercury 507 distribution in the soil-plant-air system at the Wanshan mercury mining district in Guizhou, 508 Southwest China. Environ. Toxicol. Chem. 2011, 30, 2725-2731.

509 (9) Guédron, S.; Grangeon, S.; Jouravel, G.; Charlet, L.; Sarret, G., Atmospheric mercury 510 incorporation in soils of an area impacted by a chlor-alkali plant (Grenoble, France): Contribution 511 of canopy uptake. Sci. Tot. Environ. 2013, 445, 356-364.

512 (10) Assad, M.; Parelle, J.; Cazaux, D.; Gimbert, F.; Chalot, M.; Tatin-Froux, F., Mercury uptake 513 into poplar leaves. Chemosphere 2016, 146, 1-7.

514 (11) Wang, X.; Bao, Z. D.; Lin, C. J.; Yuan, W.; Feng, X. B., Assessment of global mercury 515 deposition through litterfall. Environ. Sci. Technol. 2016, 50, 8548-8557.

516 (12) Meagher, R. B.; Heaton, A. C. P., Strategies for the engineered phytoremediation of toxic 517 element pollution: mercury and arsenic. J. Ind. Microbiol. Technol. 2005, 32, 502-513.

518 (13) Moreno, F. N.; Anderson, C. W. N.; Stewart, R. B.; Robinson, B. H., Mercury volatilisation 519 and phytoextraction from base-metal mine tailings. Environ. Poll. 2005, 136, 341-352. 
(14) Gardea-Torresdey, J. L.; Peralta-Videa, J. R.; de la Rosa, G.; Parsons, J. G., Phytoremediation of heavy metals and study of the metal coordination by X-ray absorption spectroscopy. Coord. Chem. Rev. 2005, 249, 1797-1810.

(15) Ruiz, O. N.; Alvarez, D.; Torres, C.; Roman, L.; Daniell, H., Metallothionein expression in chloroplasts enhances mercury accumulation and phytoremediation capability. Plant Biotechnol. J. 2011, 9, 609-617.

(16) Wang, J. X.; Feng, X. B.; Anderson, C. W. N.; Xing, Y.; Shang, L. H., Remediation of mercury contaminated sites - A review. J. Hazard. Mater. 2012, 221, 1-18.

(17) Wang, J. X.; Feng, X. B.; Anderson, C. W. N.; Wang, H.; Zheng, L. R.; Hu, T. D., Implications of mercury speciation in thiosulfate treated plants Environ. Sci. Technol. 2012, 46, 5361-5368.

(18) Grangeon, S.; Guedron, S.; Asta, J.; Sarret, G.; Charlet, L., Lichen and soil as indicators of an atmospheric mercury contamination in the vicinity of a chlor-alkali plant (Grenoble, France). Ecol. Indic. 2012, 13, 178-183.

(19) Chiarantini, L.; Rimondi, V.; Bardelli, F.; Benvenuti, M.; Cosio, C.; Costagliola, P.; Di Benedetto, F.; Lattanzi, P.; Sarret, G., Mercury speciation in Pinus nigra barks from Monte Amiata (Italy): An X-ray absorption spectroscopy study. Environ. Poll. 2017, 227, 83-88.

(20) Carrasco-Gil, S.; Siebner, H.; LeDuc, D. L.; Webb, S. M.; Millan, R.; Andrews, J. C.; Hernandez, L. E., Mercury localization and speciation in plants grown hydroponically or in a natural environment. Environ. Sci. Technol. 2013, 47, 3082-3090.

(21) Carrasco-Gil, S.; Alvarez-Fernandez, A.; Sobrino-Plata, J.; Millan, R.; Carpena-Ruiz, R. O.;

Leduc, D. L.; Andrews, J. C.; Abadia, J.; Hernandez, L. E., Complexation of Hg with phytochelatins is important for plant $\mathrm{Hg}$ tolerance. Plant Cell Environ. 2011, 34, 778-791.

(22) Howden, R.; Goldsbrough, P. B.; Andersen, C. R.; Cobbett, C. S., Cadmium-sensitive, cadl mutants of Arabidopsis thaliana are phytochelatin deficient. Plant Physiol. 1995, 107, 1059-1066.

(23) Cobbett, C.; Goldsbrough, P., Phytochelatins and metallothioneins: Roles in heavy metal detoxification and homeostasis. Annu. Rev. Plant Biol. 2002, 53, 159-182.

(24) Clemens, S.; Kim, E. J.; Neumann, D.; Schroeder, J. I., Tolerance to toxic metals by a gene family of phytochelatin synthases from plants and yeast. EMBO J. 1999, 18, 3325-3333.

(25) Ha, S. B.; Smith, A. P.; Howden, R.; Dietrich, W. M.; Bugg, S.; O'Connell, M. J.; Goldsbrough, P. B.; Cobbett, C. S., Phytochelatin synthase genes from arabidopsis and the yeast Schizosaccharomyces pombe. Plant Cell 1999, 11, 1153-1163. and quantification of unbound phytochelatin 2 in plant extracts of Brassica napus grown with different levels of mercury. Plant Phys. 2006, 142, 742-749. 
(27) Chen, L. Q.; Yang, L. M.; Wang, Q. Q., In vivo phytochelatins and Hg-phytochelatin complexes in Hg-stressed Brassica chinensis L. Metallomics 2009, 1, 101-106.

(28) Krupp, E. M.; Mestrot, A.; Wielgus, J.; Meharg, A. A.; Feldmann, J., The molecular form of mercury in biota: identification of novel mercury peptide complexes in plants. Chem. Comm. 2009, $28,4257-4259$.

(29) Sobrino-Plata, J.; Carrasco-Gil, S.; Abadı, J.; Escobar, C.; Alvarez-Fernandez, A.; Hernandez, L. E., The role of glutathione in mercury tolerance resembles its function under cadmium stress in Arabidopsis. Metallomics 2014, 6, 356.

(30) Raab, A.; Schat, H.; Meharg, A. A.; Feldmann, J., Uptake, translocation and transformation of arsenate and arsenite in sunflower (Helianthus annuus): formation of arsenic-phytochelatin complexes during exposure to high arsenic concentrations. New Phytol. 2005, 168, 551-558.

(31) Bluemlein, K.; Raab, A.; Feldmann, J., Stability of arsenic peptides in plant extracts: off-line versus on-line parallel elemental and molecular mass spectrometric detection for liquid chromatographic separation. Anal. Bioanal. Chem. 2009, 393, 357-366.

(32) Carey, A. M.; Lombi, E.; Donner, E.; de Jonge, M. D.; Punshon, T.; Jackson, B. P.; Guerinot, M. L.; Price, A. H.; Meharg, A. A., A review of recent developments in the speciation and location of arsenic and selenium in rice grain Anal. Bioanal. Chem. 2012, 401, 3275-3286.

(33) Raab, A.; Feldmann, J.; Meharg, A. A., The nature of arsenic-phytochelatin complexes in Holcus lanatus and Pteris cretica. Plant Physiol. 2004, 134, 1113-1122.

(34) Manceau, A.; Marcus, M. A.; Tamura, N., Quantitative speciation of heavy metals in soils and sediments by synchrotron X-ray techniques. In Applications of Synchrotron Radiation in LowTemperature Geochemistry and Environmental Science, Fenter, P. A.; Rivers, M. L.; Sturchio, N. C.; Sutton, S. R., Eds. Mineralogical Society of America: Washington, DC, 2002; Vol. 49, pp 341428.

(35) Grafe, M.; Donner, E.; Collins, R. N.; Lombi, E., Speciation of metal(loid)s in environmental samples by X-ray absorption spectroscopy: A critical review. Anal. Chim. Acta 2014, 822, 1-22.

(36) Rajan, M.; Darrow, J.; Hua, M.; Barnett, B.; Mendoza, M.; Greenfield, B. K.; Andrews, J. 583 Technol. 2008, 42, 5568-5573.

584 (37) Patty, C.; Barnett, B.; Mooney, B.; Kahn, A.; Levy, S.; Liu, Y. J.; Pianetta, P.; Andrews, J. 585 C., Using X-ray microscopy and $\mathrm{Hg} \mathrm{L}_{3}$ XANES to study $\mathrm{Hg}$ binding in the rhizosphere of Spartina cordgrass. Environ. Sci. Technol. 2009, 43, 7397-7402.

587 (38) McNear, D. H.; Afton, S. E.; Caruso, J. A., Exploring the structural basis for 588 selenium/mercury antagonism in Allium fistulosum. Metallomics 2012, 4, 267-276. 
(39) Zhao, J.; Gao, Y.; Li, Y. F.; Hu, Y. L.; Peng, X. Z.; Dong, Y.; Li, B.; Chen, C.; Chai, Z.,

590 Selenium inhibits the phytotoxicity of mercury in garlic (Allium sativum). Environ. Res. 2013, 125, $591 \quad 75-81$.

592 (40) Meng, B.; Feng, X. B.; Qiu, G. L.; Anderson, C. W. N.; Wang, J. X.; Zhao, L., Localization 593 and speciation of mercury in brown rice with implications for pan-Asian public health. Environ. 594 Sci. Technol. 2014, 48, 7974-7981.

595 (41) Kodre, A.; Arčon, I.; Debeljak, M.; Potisek, M.; Likar, M.; Vogel-Mikuš, K., Arbuscular 596 mycorrhizal fungi alter $\mathrm{Hg}$ root uptake and ligand environment as studied by X-ray absorption fine 597 structure. Environ. Exp. Bot. 2017, 133, 12-13.

598 (42) Xu, X. H.; Zhao, J. T.; Li, Y. Y.; Fan, Y. Q.; Zhu, N. L.; Gao, Y. X.; Li, B.; Liu, H. Y.; Li, 599 Y. F., Demethylation of methylmercury in growing rice plants: An evidence of self-detoxification. 600 Environ. Poll. 2016, 210, 113-120.

601 (43) Li, P.; Feng, X. B.; Qiu, G. L.; Shang, L. H.; Wang, S. F., Mercury pollution in Wuchuan 602 mercury mining area, Guizhou, Southwestern China: The impacts from large scale and artisanal 603 mercury mining. Environ. Intern. 2012, 42, 59-66.

604 (44) Du, X.; Zhu, Y. G.; Liu, W. J.; Zhao, X. S., Uptake of mercury (Hg) by seedlings of rice 605 (Oryza sativa L.) grown in solution culture and interactions with arsenate uptake. Environ. Exp. 606 Bot. 2005, 54, 1-7.

607 (45) Rovezzi, M.; Lapras, C.; Manceau, A.; Glatzel, P.; Verbeni, R., High energy-resolution x608 ray spectroscopy at ultra-high dilution with spherically bent crystal analyzers of $0.5 \mathrm{~m}$ radius. Rev. 609 Sci. Instr. 2017, 88, 013108.

610 (46) Manceau, A.; Enescu, M.; Simionovici, A.; Lanson, M.; Gonzalez-Rey, M.; Rovezzi, M.; 611 Tucoulou, R.; Glatzel, P.; Nagy, K. L.; Bourdineaud, J.-P., Chemical forms of mercury in human 612 hair reveal sources of exposure. Environ. Sci. Technol. 2016, 50, 10721-10729.

613 (47) Manceau, A.; Lemouchi, C.; Enescu, M.; Gaillot, A.-C.; Lanson, M.; Magnin, V.; Glatzel, 614 P.; Poulin, B. A.; Ryan, J. N.; Aiken, G. R.; Gautier-Luneau, I.; Nagy, K. L., Formation of mercury 615 sulfide from $\mathrm{Hg}(\mathrm{II})$-thiolate complexes in natural organic matter. Environ. Sci. Technol. 2015, 49, $6169787-9796$.

617 (48) Lannes, A.; Manceau, A.; Rovezzi, M.; Glatzel, P.; Joly, Y.; Gautier-Luneau, I., 618 Intramolecular $\mathrm{Hg} . . . \pi$ interactions of $\mathrm{d}$-character with non-bridging atoms in mercury-aryl 619 complexes. Dalton Trans. 2016, 45, 14035-14038.

620 (49) Manceau, A.; Marcus, M.; Lenoir, T., Estimating the number of pure chemical components 621 in a mixture by X-ray absorption spectroscopy. J. Synchrotron Radiat. 2014, 21, 1140-1147. 
(50) Wilcox, J.; Rupp, E.; Ying, S. C.; Lim, D. H.; Negreira, A. S.; Kirchofer, A.; Feng, F.; Lee,

623 K., Mercury adsorption and oxidation in coal combustion and gasification processes. Int. J. Coal Geol. 2012, 90, 4-20.

(51) Lim, D. H.; Wilcox, J., Heterogeneous mercury oxidation on Au(111) from first principles. Environ. Sci. Technol. 2013, 47, 8515-8522.

(52) Enescu, M.; Manceau, A., High-level ab initio calculation of the stability of mercury-thiolate complexes. Theor. Chem. Acc. 2014, 133, n 1457.

(53) Manceau, A.; Lemouchi, C.; Rovezzi, M.; Lanson, M.; Glatzel, P.; Nagy, K. L.; GautierLuneau, I.; Joly, Y.; Enescu, M., Structure, bonding, and stability of mercury complexes with thiolate and thioether ligands from high-resolution XANES spectroscopy and first-principles calculations. Inorg. Chem. 2015, 54, 11776-11791.

(54) Tang, X. Y.; Zheng, A. X.; Shang, H.; Yuan, R. X.; Li, H. X.; Ren, Z. G.; Lang, J. P., Binding of a coordinatively unsaturated mercury(II) thiolate compound by carboxylate anions. Inorg. Chem. 2011, 50, 503-516.

(55) Møller, C.; Plesset, M. S., Note on an approximation treatment for many-electron systems. Phys. Rev. 1934, 46, 618-622.

(56) Neese, F., The ORCA program system. WIREs Comput. Mol. Sci. 2012, 2, 73-78.

(57) Enescu, M.; Nagy, K. L.; Manceau, A., Nucleation of mercury sulfide by dealkylation. Sci. $640 \quad$ Rep. 2016, 6, 39359.

641 (58) Obrist, D.; Pokharel, A. K.; Moore, C., Vertical profile measurements of soil air suggest 642 immobilization of gaseous elemental mercury in mineral soil. Environ. Sci. Technol. 2014, 48, $6432242-2252$.

644 (59) Qiu, G. L.; Feng, X. B.; Wang, S. F.; Shang, L. H., Environmental contamination of mercury 645 from Hg-mining areas in Wuchuan, northeastern Guizhou, China. Environ. Poll. 2006, 142, 549646558.

647 (60) Frescholtz, T. F.; Gustin, M. S.; Schorran, D. E.; Fernandez, G. C. J., Assessing the source 648 of mercury in foliar tissue of quaking aspen. Environ. Toxicol. Chem. 2003, 22, 2114-2119.

649 (61) Ericksen, J. A.; Gustin, M. S.; Schorran, D. E.; Johnson, D. W.; Lindberg, S. E.; Coleman, J. 650 S., Accumulation of atmospheric mercury in forest foliage. Atm. Environ. 2003, 37, 1613-1622.

651 (62) Millhollen, A. G.; Gustin, M. S.; Obrist, D., Foliar mercury accumulation and exchange for 652 three tree species. Environ. Sci. Technol. 2006, 40, 6001-6006.

653 (63) Millhollen, A. G.; Obrist, D.; Gustin, M. S., Mercury accumulation in grass and forb species 654 as a function of atmospheric carbon dioxide concentrations and mercury exposures in air and soil. 655 Chemosphere 2006, 65, 889-897. 
(64) Laacouri, A.; Nater, E. A.; Kolka, R. K., Distribution and uptake dynamics of mercury in leaves of common deciduous tree species in Minnesota, USA. Environ. Sci. Technol. 2013, 47, 10462-10470.

(65) Cavallini, A.; Natali, L.; Durante, M.; Maserti, B., Mercury uptake, distribution and DNA affinity in durum wheat (Triticum durum Desf.) plants. Sci. Tot. Environ. 1999, 243, 119-127.

(66) Cui, L. W.; Feng, X. B.; Lin, C. J.; Wang, X. M.; Meng, B.; Wang, X.; Wang, H., Accumulation and translocation of ${ }^{198} \mathrm{Hg}$ in four crop species. Environ. Toxicol. Chem. 2014, 33, 334-340.

665

666

667

668

669

670

671

672

673

674

675

676

(67) Jew, A. D.; Kim, C. S.; Rytuba, J. J.; Gustin, M. S.; Brown, G. E., New technique for quantification of elemental $\mathrm{Hg}$ in mine wastes and its implications for mercury evasion into the atmosphere. Environ. Sci. Technol. 2011, 45, 412-417.

(68) Skyllberg, U.; Bloom, P. R.; Qian, J.; Lin, C. M.; Bleam, W. F., Complexation of mercury(II) in soil organic matter: EXAFS evidence for linear two-coordination with reduced sulfur groups. Environ. Sci. Technol. 2006, 40, 4174-4180.

(69) Nagy, K. L.; Manceau, A.; Gasper, J. D.; Ryan, J. N.; Aiken, G. R., Metallothionein-like multinuclear clusters of mercury(II) and sulfur in peat. Environ. Sci. Technol. 2011, 45, 72987306.

(70) Kim, C. S.; Bloom, N. S.; Rytuba, J. J.; Brown, G. E., Mercury speciation by X-ray absorption fine structure spectroscopy and sequential chemical extractions: A comparison of speciation methods. Environ. Sci. Technol. 2003, 37, 5102-5108.

(71) Potter, R. W.; Barnes, H. L., Phase relations in the binary Hg-S. Am. Miner. 1978, 63, 11431152.

(72) Cardona, M.; Kremer, R. K.; Lauck, R.; Siegle, G.; Munoz, A.; Romero, A. H., Electronic, vibrational, and thermodynamic properties of metacinnabar $\beta-\mathrm{HgS}, \mathrm{HgSe}$, and HgTe. Phys. Rev. B 2009, 80, 195204

(73) Bell, A. M. T.; Pattrick, R. A. D.; Vaughan, D. J., Structural evolution of aqueous mercury sulphide precipitates: energy-dispersive X-ray diffraction studies. Min. Mag. 2010, 74, 85-96.

(74) Baldi, F.; Gallo, M.; Daniele, S.; Battistel, D.; Faleri, C.; Kodre, A.; Arcon, I., An extracellular polymeric substance quickly chelates mercury(II) with $\mathrm{N}$-heterocyclic groups. Chemosphere 2017, 176, 296-304.

(75) Schiering, N.; Kabsch, W.; Moore, M. J.; Distefano, M. D.; Walsh, C. T.; Pai, E. F., Structure of the detoxification catalyst mercuric ion reductase from Bacillus sp. strain RC607. Nature 1991, $352,168-172$. 
(76) Pufahl, R. A.; Singer, C. P.; Peariso, K. L.; Lin, S. J.; Schmidt, P. J.; Fahrni, C. J.; Culotta,

690 V. C.; Penner-Hahn, J. E.; Ohalloran, T. V., Metal ion chaperone function of the soluble Cu(I) receptor Atx1. Science 1997, 278, 853-856.

692 (77) Steele, R. A.; Opella, S. J., Structures of the reduced and mercury-bound forms of MerP, the 693 periplasmic protein from the bacterial mercury detoxification system. Biochemistry 1997, 36, 68856946895.

695

696

697

698

699

700

701

702

703

704

705

706

707

708

709

710

711

712

713

714

715

716

717

718

719

720

721

722

(78) Rosenzweig, A. C.; Huffman, D. L.; Hou, M. Y.; Wernimont, A. K.; Pufahl, R. A.; O'Halloran, T. V., Crystal structure of the Atx1 metallochaperone protein at 1.02 angstrom resolution. Structure 1999, 7, 605-617.

(79) Wernimont, A. K.; Huffman, D. L.; Lamb, A. L.; O'Halloran, T. V.; Rosenzweig, A. C., Structural basis for copper transfer by the metallochaperone for the Menkes/Wilson disease proteins. Nature Str. Biol. 2000, 7, 766-771.

(80) Wilson, J. R.; Leang, C.; Morby, A. P.; Hobman, J. L.; Brown, N. L., MerF is a mercury transport protein: different structures but a common mechanism for mercuric ion transporters? FEBS Lett. 2000, 472, 78-82.

(81) Serre, L.; Rossy, E.; Pebay-Peyroula, E.; Cohen-Addad, C.; Coves, J., Crystal structure of the oxidized form of the periplasmic mercury-binding protein MerP from Ralstonia metallidurans CH34. J. Mol. Biol. 2004, 339, 161-171.

(82) Mah, V.; Jalilehvand, F., Glutathione complex formation with mercury(II) in aqueous solution at physiological pH. Chem. Res. Toxicol. 2010, 23, 1815-1823.

(83) Luczkowski, M.; Zeider, B. A.; Hinz, A. V. H.; Stachura, M.; Chakraborty, S.; Hemmingsen, L.; Huffman, D. L.; Pecoraro, V. L., Probing the coordination environment of the human copper chaperone HAH1: Characterization of $\mathrm{Hg}^{\mathrm{II}}$-bridged homodimeric species in solution. Chem. - Eur. J. 2013, 19, 9042-9049.

(84) Lian, P.; Guo, H. B.; Riccardi, D.; Dong, A. P.; Parks, J. M.; Xu, Q.; Pai, E. F.; Miller, S. M.; Wei, D. Q.; Smith, J. C.; Guo, H., X-ray structure of a $\mathrm{Hg}^{2+}$ complex of mercuric reductase (MerA) and quantum mechanical/molecular mechanical study of $\mathrm{Hg}^{2+}$ transfer between the Cterminal and buried catalytic site cysteine pairs. Biochemistry 2014, 53, 7211-7222.

(85) Muradoglu, F.; Gündogdu, M., Stomata size and frequency in some walnut (Juglans regia) cultivars. Int. J. Agric. Biol. 2011, 13, 1011-1015.

(86) Bondada, B.; Tu, C.; Ma, L., Surface structure and anatomical aspects of Chinese brake fern (Pteris vittata; Pteridaceae). Brittonia 2006, 58, 217-228.

(87) Lee, J.; Shim, D.; Song, W. Y.; Hwang, I.; Lee, Y., Arabidopsis metallothioneins 2a and 3 enhance resistance to cadmium when expressed in Vicia faba guard cells. Plant Mol. Biol. 2004, $54,805-815$. 
(88) Peroza, E. A.; Schmucki, R.; Guntert, P.; Freisinger, E.; Zerbe, O., The $\beta_{\mathrm{E}-\text {-domain of wheat }}$ $\mathrm{E}_{\mathrm{c}-1}$ metallothionein: A metal-binding domain with a distinctive structure. J. Mol. Biol. 2009, 387, 207-218.

(89) Freisinger, E., The metal-thiolate clusters of plant metallothioneins. Chimia 2010, 64, 217224.

(90) Perfus-Barbeoch, L.; Leonhardt, N.; Vavasseur, A.; Forestier, C., Heavy metal toxicity: 730 cadmium permeates through calcium channels and disturbs the plant water status. Plant J. 2002, $73132,539-548$.

(91) Zhu, M.; Zhu, N. L.; Song, W. Y.; Harmon, A. C.; Assmann, S. M.; Chen, S., Thiol-based redox proteins in Brassica napus guard cell abscisic acid and methyl jasmonate signaling. Plant J. 2014, 78, 491-515.

(92) Peroza, E. A.; Al Kaabi, A.; Meyer-Klaucke, W.; Wellenreuther, G.; Freisinger, E., The two distinctive metal ion binding domains of the wheat metallothionein $\mathrm{E}_{\mathrm{c}}-1$. J. Inorg. Biochem. 2009, $103,342-353$.

(93) Loebus, J.; Peroza, E. A.; Bluthgen, N.; Fox, T.; Meyer-Klaucke, W.; Zerbe, O.; Freisinger, E., Protein and metal cluster structure of the wheat metallothionein domain $\gamma$-E-c-1: the second part of the puzzle. J. Biol. Inorg. Chem. 2011, 16, 683-694.

(94) Tarasava, K.; Freisinger, E., Investigating the influence of histidine residues on the metal ion binding ability of the wheat metallothionein $\gamma-\mathrm{E}_{\mathrm{c}-1}$ domain. J. Inorg. Biochem. 2015, 153, 197203.

(95) Freisinger, E., Spectroscopic characterization of a fruit-specific metallothionein: $M$. acuminata MT3. Inorg. Chim. Acta 2007, 360, 369-380.

(96) Domenech, J.; Mir, G.; Huguet, G.; Capdevila, M.; Molinas, M.; Atrian, S., Plant metallothionein domains: functional insight into physiological metal binding and protein folding. Biochimie 2006, 88, 583-593.

(97) Romero-Isart, N.; Vasak, M., Advances in the structure and chemistry of metallothioneins.

751 (98) Freisinger, E., Plant MTs-long neglected members of the metallothionein superfamily. Dalton Trans. 2008, 47, 6663-6675.

753 (99) Freisinger, E., Structural features specific to plant metallothioneins. J. Biol. Inorg. Chem. 754 2011, 16, 1035-1045.

755 (100) Blindauer, C. A.; Harrison, M. D.; Parkinson, J. A.; Robinson, A. K.; Cavet, J. S.; Robinson, 756 N. J.; Sadler, P. J., A metallothionein containing a zinc finger within a four-metal cluster protects 757 a bacterium from zinc toxicity. Proc. Natl. Acad. Sci. U.S.A. 2001, 98, 9593-9598. 
(101) Digilio, G.; Bracco, C.; Vergani, L.; Botta, M.; Osella, D.; Viarengo, A., The cadmium binding domains in the metallothionein isoform Cd-7-MT10 from Mytilus galloprovincialis revealed by NMR spectroscopy. J. Biol. Inorg. Chem. 2009, 14, 167-178.

(102) Schicht, O.; Freisinger, E., Spectroscopic characterization of Cicer arietinum metallothionein 1. Inorg. Chim. Acta 2009, 362, 714.

763

(103) Bowmaker, G. A.; Dance, I. G.; Harris, R. K.; Henderson, W.; Laban, I.; Scudder, M. L.;

Oh, S. W., Crystallographic, vibrational and nuclear magnetic resonance spectroscopic characterization of the $\left[(\mathrm{PhS})_{2} \mathrm{Hg}(\mu-\mathrm{SPh})_{2} \mathrm{Hg}(\mathrm{SPh})_{2}\right]^{2-}$ ion. J. Chem. Soc.-Dalton Trans. 1996, 2381-2388.

(104) Melnick, J. G.; Yurkerwich, K.; Parkin, G., On the chalcogenophilicity of mercury: Evidence for a strong $\mathrm{Hg}$-Se bond in $\left[\mathrm{Tm}^{\mathrm{But}}\right] \mathrm{HgSePh}$ and its relevance to the toxicity of mercury. J. Am. Chem. Soc. 2010, 132, 647-655.

(105) Bowmaker, G. A.; Dance, I. G.; Dobson, B. C.; Rogers, D. A., Syntheses and vibrational spectra of some tris(alkanethiolato)mercurate(II) complexes, and crystal structure of the Hexakis(methanethiolato)dimercurate(II) dianion. Aust. J. Chem. 1984, 37, 1607-1618.

(106) Enescu, M.; Renault, J. P.; Pommeret, S.; Mialocq, J. C.; Pin, S., Ab initio study of Cd-thiol complexes: application to the modelling of the metallothionein active site. Phys. Chem. Chem. Phys. 2003, 5, 3762-3767.

(107) Manceau, A.; Nagy, K. L., Relationships between $\mathrm{Hg}(\mathrm{II})-\mathrm{S}$ bond distance and $\mathrm{Hg}(\mathrm{II})$ coordination in thiolates. Dalton Trans. 2008, 11, 1421-1425.

(108) Rodic, D.; Spasojevic, V.; Bajorek, A.; Onnerud, P., Similarity of structure properties of $\mathrm{Hg}_{1-\mathrm{x}} \mathrm{Mn}_{\mathrm{x}} \mathrm{S}$ and $\mathrm{Cd}_{1-\mathrm{x}} \mathrm{Mn}_{\mathrm{x}} \mathrm{S}$ (structure properties of $\mathrm{HgMnS}$ and $\mathrm{CdMnS}$ ). J. Mag. Mag. Mater. 1996, 152, 159-164.

(109) Frenkel, A. I.; Yevick, A.; Cooper, C.; Vasic, R., Modeling the structure and composition of nanoparticles by extended X-ray absorption fine-structure spectroscopy. In Ann. Rev. Anal. Chem., Cooks, R. G.; Yeung, E. S., Eds. 2011; Vol. 4, pp 23-39.

(110) Ankudinov, A. L.; Rehr, J. J.; Low, J. J.; Bare, S. R., Sensitivity of Pt X-ray absorption near edge structure to the morphology of small Pt clusters. J. Chem. Phys. 2002, 116, 1911-1919.

(111) Demchenko, I. N.; Denlinger, J. D.; Chernyshova, M.; Yu, K. M.; Speaks, D. T.; Olaldemultiple scattering analysis of XANES at the $\mathrm{Cd} L_{3}$ and $\mathrm{O} K$ edges in $\mathrm{CdO}$ films combined with a soft-x-ray emission investigation. Phys. Rev. B 2010, 82, 075107.

(112) Gardea-Torresdey, J. L.; Tiemann, K. J.; Parsons, J. G.; Gamez, G.; Herrera, I.; JoseYacaman, M., XAS investigations into the mechanism(s) of $\mathrm{Au}(\mathrm{III})$ binding and reduction by alfalfa biomass. Microchem. J. 2002, 71, 193-204. 
(113) Gardea-Torresdey, J. L.; Parsons, J. G.; Gomez, E.; Peralta-Videa, J.; Troiani, H. E.; 794 Santiago, P.; Yacaman, M. J., Formation and growth of Au nanoparticles inside live alfalfa plants. Nano Lett. 2002, 4, 397-401.

(114) Gardea-Torresdey, J. L.; Gomez, E.; Peralta-Videa, J. R.; Parsons, J. G.; Troiani, H. E.; Yacaman, M. J., Alfalfa sprouts: A natural source for the synthesis of silver nanoparticles. Langmuir 2003, 19, 1357-1361.

(115) Manceau, A.; Nagy, K. L.; Marcus, M. A.; Lanson, M.; Geoffroy, N.; Jacquet, T.; 800 Kirpichtchikova, T., Formation of metallic copper nanoparticles at the soil-root interface. Environ. 801 Sci. Technol. 2008, 42, 1766-1772.

802 (116) Das, R. K.; Pachapur, V. L.; Linson Lonappan, L.; Naghdi, M.; Pulicharla, R.; Maiti, S.; 803 Cledon, M.; Dalila, L. M. A.; Sarma, S. J.; Brar, S. K., Biological synthesis of metallic 804 nanoparticles: plants, animals and microbial aspects. Nanotechnol. Environ. Eng. 2017, 2, 18.

805 (117) Marcos, E.; Basanta, B.; Chidyausiku, T. M.; Tang, Y.; Oberdorfer, G.; Liu, G.; Swapna, 806 G. V. T.; Guan, R.; Silva, D. A.; Jiayi Dou; Pereira, J. H.; Xiao, R.; Sankaran, B.; Zwart, P. H.; 807 Montelione, G. T.; Baker, D., Principles for designing proteins with cavities formed by curved $\beta$ 808 sheets. Science 2017, 355, 201-206.

809 (118) Frazier, J. M.; George, S. S.; Overnell, J.; Coombs, T. L.; Kagi, J., Characterization of two 810 molecular weight classes of cadmium binding proteins from the mussel, Mytilus edulis (L). Comp. 811 Biochem. Physiol. C 1985, 80, 257-262.

812 (119) Frazier, J. M., Cadmium-binding proteins in the Mussel, Mytilus edulis. Environ. Health 813 Persp. 1986, 65, 39-43.

814 (120) Mackay, E. A.; Overnell, J.; Dunbar, B.; Davidson, I.; Hunziker, P. E.; Kagi, J. H. R.; 815 Fothergill, J. E., Complete amino acid sequences of five dimeric and four monomeric forms of 816 metallothionein from the edible mussel Mytilus edulis. Eur. J. Biochem. 1993, 218, 183-194.

817 (121) Barsyte, D.; White, K. N.; Lovejoy, D. A., Cloning and characterization of metallothionein 818 cDNAs in the mussel Mytilus edulis L. digestive gland. Comp. Biochem. Physiol. C 1999, 122, $819 \quad 287-296$.

820 (122) Lemoine, S.; Bigot, Y.; Sellos, D.; Cosson, R. P.; Laulier, M., Metallothionein isoforms in 821 Mytilus edulis (Mollusca, Bivalvia): Complementary DNA characterization and quantification of 822 expression in different organs after exposure to cadmium, zinc, and copper. Marine Biotechnol. $8232000,2,195-203$.

824 (123) Ivankovic, D.; Pavicic, J.; Kozar, S.; Raspor, B., Multiple forms of metallothionein from 825 the digestive gland of naturally occurring and cadmium-exposed mussels, Mytilus 826 galloprovincialis. Helgol. Mar. Res. 2002, 56, 95-101. 
(124) Kim, J. S.; Rees, D. C., Structural models for the metal centers in the nitrogenase molybdenum-iron protein. Science 1992, 257, 1677-1682.

(125) Lee, G. S. H.; Fisher, K. J.; Vassallo, A. M.; Hanna, J. V.; Dance, I. G., Solid-state ${ }^{113}$ Cd NMR of three structural isomers of $\left[\mathrm{S}_{4} \mathrm{Cd}_{10}(\mathrm{SPh}]_{16}\right]^{4-}$. Inorg. Chem. 1993, 32, 66-72.

(126) Beinert, H.; Holm, R. H.; Munck, E., Iron-sulfur clusters: Nature's modular, multipurpose structures. Science 1997, 277, 653-659.

(127) Gelinsky, M.; Vahrenkamp, H., Oligonuclear benzylthiolate zinc complexes. Z. Anorg. Allg. Chem. 2002, 628, 1017-1021.

(128) Rao, P. V.; Holm, R. H., Synthetic analogues of the active sites of iron-sulfur proteins. Chem. Rev. 2004, 104, 527-559.

(129) Fritsch, J.; Scheerer, P.; Frielingsdorf, S.; Kroschinsky, S.; Friedrich, B.; Lenz, O.; Spahn, C. M. T., The crystal structure of an oxygen-tolerant hydrogenase uncovers a novel iron-sulphur centre. Nature 2011, 249-U134.

(130) Pan, Y. H.; Sader, K.; Powell, J. J.; Bleloch, A.; Gass, M.; Trinick, J.; Warley, A.; Li, A.; Brydson, R.; Brown, A., 3D morphology of the human hepatic ferritin mineral core: New evidence for a subunit structure revealed by single particle analysis of HAADF-STEM images. J. Str. Biol. 2009, 166, 22-31.

(131) Jian, N.; Dowle, M.; Horniblow, R. D.; Tselepis, C.; Palmer, R. E., Morphology of the ferritin iron core by aberration corrected scanning transmission electron microscopy. Nanotechnol. 2016, 27, 46LT02.

(132) Pozzi, C.; Ciambellotti, S.; Bernacchioni, C.; Di Pisa, F.; Mangani, S.; Turano, P., Chemistry at the protein-mineral interface in L-ferritin assists the assembly of a functional $\left(\mu^{3}\right.$ oxo)Tris ( $\mu^{2}$-peroxo) triiron(III) cluster. Proc. Natl. Acad. Sci. U.S.A. 2017, 114, 2580-2585.

(133) Pires, S.; Habjanic, J.; Sezer, M.; Soares, C. M.; Hemmingsen, L.; Iranzo, O., Design of a peptidic turn with high affinity for $\mathrm{Hg}^{\mathrm{II}}$. Inorg. Chem. 2012, 51, 11339-11348.

(134) Brust, M.; Walker, M.; Bethell, D.; Schiffrin, D. J.; Whyman, R., Synthesis of thiolderivatised gold nanoparticles in a two-phase liquid-liquid system. J. Chem. Soc., Chem. Commun. 1994, 7, 801-802.

(135) Higginson, K. A.; Kuno, M.; Bonevich, J.; Qadri, S. B.; Yousuf, M.; Mattoussi, H., Synthesis and characterization of colloidal $\beta-\mathrm{HgS}$ quantum dots. J. Phys. Chem. B 2002, 106, 99829985.

(136) Zhang, P.; Sham, T. K., X-ray studies of the structure and electronic behavior of alkanethiolate-capped gold nanoparticles: The interplay of size and surface effects. Phys. Rev. Lett. 2003, 90, 245502. 
(137) Frenkel, A. I.; Nemzer, S.; Pister, I.; Soussan, L.; Harris, T.; Sun, Y.; Rafailovich, M. H., 862 Size-controlled synthesis and characterization of thiol-stabilized gold nanoparticles. J. Chem. Phys. 2005, 123, 208-213.

(138) Jadzinsky, P. D.; Calero, G.; Ackerson, C. J.; Bushnell, D. A.; Kornberg, R. D., Structure of a thiol monolayer-protected gold nanoparticle at 1.1 angstrom resolution. Science 2007, 318, 430-433.

(139) Whetten, R. L.; Price, R. C., Nano-golden order. Science 2007, 318, 407-408.

(140) Simms, G. A.; Padmos, J. D.; Zhang, P., Structural and electronic properties of protein/thiolate-protected gold nanocluster with "staple" motif: A XAS, L-DOS, and XPS study. J. Chem. Phys. 2009, 131, 214703.

(141) Ariyasu, S.; Onoda, A.; Sakamoto, R.; Yamamura, T., Conjugation of Au11 cluster with Cys-rich peptides containing the $\alpha$-domain of metallothionein. Dalton Trans. 2009, 19, 3742-3747. (142) Liu, X.; Liu, R.; Tang, Y. R.; Zhang, L. C.; Hou, X. D.; Lv, Y., Antibody-biotemplated HgS nanoparticles: Extremely sensitive labels for atomic fluorescence spectrometric immunoassay. Analyst 2012, 137, 1473-1480.

(143) Schwerdtfeger, P.; Li, J.; Pyykko, P., The polarizability of $\mathrm{Hg}$ and the ground-state interaction potential of $\mathrm{Hg}_{2}$. Theor. Chim. Acta 1994, 87, 313-320.

(144) Pyykko, P.; Straka, M., Ab initio studies of the dimers $\left(\mathrm{HgH}_{2}\right)_{2}$ and $\left(\mathrm{HgMe}_{2}\right)_{2}$. Metallophilic attraction and the van der Waals radii of mercury. Phys. Chem. Chem. Phys. 2000, 2, 2489-2493. (145) Capdevila, M.; Domenech, J.; Pagani, A.; Tio, L.; Villarreal, L.; Atrian, S., Zn- and Cdmetallothionein recombinant species from the most diverse phyla may contain sulfide $\left(\mathrm{S}^{2-}\right)$ ligands. Angew. Chem., Int. Ed. 2005, 44, 4618-4622.

(146) Alvarez, C.; Calo, L.; Romero, L. C.; Garcia, I.; Gotor, C., An O-acetylserine(thiol)lyase homolog with L-cysteine desulfhydrase activity regulates cysteine homeostasis in Arabidopsis. Plant Phys. 2010, 152, 656-669.

(147) Thomas, S. A.; Gaillard, J. F., Cysteine addition promotes sulfide production and four-fold $\mathrm{Hg}(\mathrm{II})-\mathrm{S}$ coordination in actively metabolizing Escherichia coli. Environ. Sci. Technol. 2017, 51, 4642-4651.

(148) Jia, H. L.; Wang, X. F.; Dou, Y. H.; Liu, D.; Si, W. T.; Fang, H.; Zhao, C.; Chen, S. L.; Xi, J. J.; Li, J. S., Hydrogen sulfide - cysteine cycle system enhances cadmium tolerance through alleviating cadmium-induced oxidative stress and ion toxicity in Arabidopsis roots. Sci. Rep. 2016, 6, 39702.

(149) Ye, H.; Garifullina, G. F.; Abdel-Ghany, S. E.; Zhang, L. H.; Pilon-Smits, E. A. H.; Pilon, M., The chloroplast NifS-like protein of Arabidopsis thaliana is required for iron-sulfur cluster formation in ferredoxin. Planta 2005, 220, 602-608. 
(150) Li, Q.; Cao, J. H., Structure of leaf epidermis and ecology adaptation of Vitex negundo L. at Karat area in southwest China. J. Henan Normal Univ. 2008, 36, 131-134.

898 (151) Driscoll, S. P.; Prins, A.; Olmos, E.; Kunert, K. J.; Foyer, C. H., Specification of adaxial and abaxial stomata, epidermal structure and photosynthesis to $\mathrm{CO}_{2}$ enrichment in maize leaves. $J$. Exp. Bot. 2006, 57, 381-390.

901 (152) Waldron, K. J.; Rutherford, J. C.; Ford, D.; Robinson, N. J., Metalloproteins and metal 902 sensing. Nature 2009, 460, 823-830.

903 (153) Ralston, D. M.; Ohalloran, T. V., Ultrasensitivity and heavy-metal selectivity of the 904 allosterically modulated MerR transcription complex. Proc. Natl. Acad. Sci. USA 1990, 87, 38469053850.

906 (154) Hintelmann, H.; Harris, R.; Heyes, A.; Hurley, J. P.; Kelly, C. A.; Krabbenhoft, D. P.; 907 Lindberg, S.; Rudd, J. W. M.; Scott, K. J.; St Louis, V. L., Reactivity and mobility of new and old 908 mercury deposition in a Boreal forest ecosystem during the first year of the METAALICUS study. 909 Environ. Sci. Technol. 2002, 36, 5034-5040.

910 (155) Auvray, P.; Genet, F., Affinement de la structure cristalline du cinabre $\alpha$-HgS. Bull. Soc. 911 Fr. Mineral. Cristallogr. 1973, 96, 218-219.

912

\section{FIGURE LEGENDS}

914 Figure 1. Concentration of mercury in leaf tissues and ambient air (a) and ternary plot of the 915 proportions of the three $\mathrm{Hg}$ species in leaf tissues (b). $\mathrm{Pv}$ : Pteris vittata; Vn: Vitex negundo; Ds: 916 Desmodium sequax wall; Do: Debregeasia orientalis; Jr: Juglans regia; Po: Platycladus orientalis.

917 The number after each sample code is the concentration in $\mathrm{ng} \mathrm{Hg} \mathrm{mg}^{-1}$ (ppm) dry weight (dwt).

$918 \mathrm{Sp} 1$ and $\mathrm{Sp} 2$ are two dithiolate complexes. Nano $\beta-\mathrm{HgS}$ is nanoparticulate metacinnabar. ${ }^{47}$

919

920 Figure 2. Mercury speciation in the mined $\mathrm{Hg}$ ore and in Soill6 by $\mathrm{L}_{3}$-edge HR-XANES 921 spectroscopy. a) $\mathrm{Hg}$ in the ore is in the form of cinnabar $(\alpha-\mathrm{HgS})$. b) At least $90 \%$ of the $\mathrm{Hg}$ present 922 in Soill6 is precipitated as nanoparticulate metacinnabar $\left(\beta-\mathrm{Hg} \mathrm{S}_{\mathrm{NP}}\right)$. The $\beta$ - $\mathrm{HgS} \mathrm{S}_{\mathrm{NP}}$ reference is 923 from the A horizon of a contaminated soil situated downstream from Oak Ridge, TN, in the United 924 States. $^{47}$ Polyhedral representations are of the $\alpha-\mathrm{HgS}$ and $\beta$-HgS structures. ${ }^{108,}{ }^{155}$ Dark red and 925 yellow represent $\mathrm{Hg}$ and $\mathrm{S}$, respectively. The $\alpha$ allotrope features an array of parallel ...S-Hg-S- 
$926 \mathrm{Hg}-\mathrm{S} \ldots$ chains and the $\beta$ allotrope a 3D assemblage of corner-sharing $\mathrm{HgS}_{4}$ tetrahedra. The linear

927 and tetrahedral coordinations of $\mathrm{Hg}$ provide distinct spectral signatures.

929 Figure 3. Mercury speciation in soils by L3-edge HR-XANES spectroscopy. a) Two dominant $\mathrm{Hg}$ 930 forms are present in Soil44 and Soil88: $\alpha-\mathrm{HgS}$ represented by the $\mathrm{Hg}$ ore spectrum and $\beta-\mathrm{HgS} \mathrm{NP}_{\mathrm{P}}$ 931 represented by the Soil16 spectrum (Figure 2b). b-f) Linear least-squares combination fits of the 932 multicomponent soil spectra with two (2cp) or three (3cp) spectra from single species.

934 Figure 4. The three outliers spectra from the twenty-four leaf spectra. a) The Ds4 and Pv25 spectra 935 are from single species denoted $\mathrm{Sp} 1$ and $\mathrm{Sp} 2$, respectively. Their intense near-edge peak is 936 diagnostic of a linear RS-Hg-SR bonding. ${ }^{53}$ The near-edge and the following peak (arrow) from 937 Vn6 have lower amplitude and the signal immediately after the edge maximum is shifted left. These 938 changes indicate a tetrahedral coordination with four sulfur atoms as in $\beta-\mathrm{HgS}{ }^{53} \mathrm{~b}$ ) The Ds4 939 spectrum is close to Hg-PC2. c) Linear least-squares fit to the Vn6 spectrum with $45 \pm 8$ mol \% $940 \mathrm{Sp} 1$ and $55 \pm 8 \mathrm{~mol} \% \beta-\mathrm{HgS}_{\mathrm{NP}}$ d) Geometry-optimized $\mathrm{Hg}$-PC2 complex. $\mathrm{Hg}$ is bonded to the 941 two cysteinyl $\mathrm{S}$ atoms ${ }^{28}$ and to two carbonyl oxygens forming a double six-membered bis942 (oxo)thiolate ring chelate $\left(\mathrm{Hg}(\mathrm{SR}+\mathrm{O})_{2}\right.$ coordination). The peptide forms a scaffold for the $\mathrm{Hg}$ 943 complex, and the molecular cage is stabilized by one hydrogen bond between a carbonyl oxygen 944 and an amide proton, as is customary for the secondary structure of proteins. Cartesian coordinates 945 are given in the SI. Dark red, Hg; yellow, S; blue, N; red, O; gray, C; light gray, H.

947 Figure 5. Estimation of the $\mathrm{Hg}_{\mathrm{x}} \mathrm{S}_{\mathrm{y}}$ cluster size in plant leaves from the shape of the HR-XANES 948 edge maximum. The upper part of the edge for Po2 and $\mathrm{Vn6}$, which contain 57\% and 55\% $\beta-\mathrm{HgS} \mathrm{SP}_{\mathrm{NP}}$ 949 respectively, is structured (see also Figure 4a) whereas MT2 has a featureless bell-shape. Variations 950 of the absorption signal in this energy region come from medium-range $\mathrm{Hg}$ shells, which the MT 951 clusters lack owing to their small size (maximum $\mathrm{Hg}-\mathrm{Hg}$ distance is $\sim 7 \AA$ ). 
953 Figure 6. Detection of a cinnabar $(\alpha-\mathrm{HgS})$ sand-sized grain in a $5 \mathrm{~mm}$ diameter pressed pellet from 954 the lyophilized Vn30 leaf tissue. a) 108 HR-XANES spectra were measured for $20 \mathrm{~s}$ by rastering a $955700 \times 80 \mu \mathrm{m}^{2}(\mathrm{H} \mathrm{x} \mathrm{V}) \mathrm{X}$-ray beam on the sample pellet. The clump of point spectra is from the leaf 956 tissue. The point spectrum on top with a higher absorbance is from both the leaf tissue and a $\mathrm{Hg}$ 957 rich dust particle which remained at the surface of a leaf during the sample preparation and is now 958 inside the pellet. The group of leaf spectra with a lower absorbance was taken on the pellet rim. b) 959 Comparison of the point spectrum to the average spectrum from the leaf tissue (Vn30) and the $\mathrm{Hg}$ 960 ore (well-crystallized $\alpha-\mathrm{HgS}$ ). c) Linear combination fit.

962 Figure 7. Polyhedral representation of organic and inorganic $\operatorname{Hg}_{\mathrm{x}} \mathrm{S}_{\mathrm{y}}$ cluster models. a) Geometry963 optimized $\mathrm{Hg}_{3}(\mathrm{SMe})_{9}$ cluster featuring the binding of $\mathrm{Hg}$ to the $\mathrm{Me}_{3}{ }_{3} \mathrm{Cys} 9$ site of the MT $\beta_{\mathrm{E}}$ domain 964 of plants. ${ }^{88}$ b) $\left\{\mathrm{Hg}_{3} \mathrm{~S}_{9}\right\}$ motif of $\beta-\mathrm{HgS}$ showing the analogy of the connectivity of the $\left\{\mathrm{HgS}_{4}\right\}$ 965 tetrahedra in the organic (MT) and inorganic $(\beta-\mathrm{HgS}) \mathrm{Hg}_{3} \mathrm{~S}_{9}$ clusters. c) Geometry-optimized $966 \mathrm{Hg}_{4}(\mathrm{SMe})_{11}$ cluster featuring the binding of $\mathrm{Hg}$ to the $\mathrm{Me}^{\mathrm{II}}{ }_{4} \mathrm{Cys}_{11}$ site of the $\alpha$ domain of animal 967 MTs. $\left.{ }^{97} \mathrm{~d}\right)\left\{\mathrm{Hg}_{4} \mathrm{~S}_{10}\right\}$ motif of $\beta-\mathrm{HgS}$. The topology is different from that of the $\mathrm{Me}^{\mathrm{II}}{ }_{4} \mathrm{Cys}_{11}-\alpha$ cluster. 968 In a tetranuclear $\beta$-HgS-type cluster each tetrahedron shares three bridging sulfurs ( $\mu_{2}-\mathrm{S}$ type) 969 yielding an adamantane-type cage. In $\mathrm{Me}_{4}{ }_{4} \mathrm{Cys}_{11}-\alpha$, only two tetrahedra have three $\mu_{2}$ bridging 970 sulfurs, and the two other have two $\mu_{2}$ bridging sulfurs. e) Geometry-optimized $\mathrm{Hg}_{4}(\mathrm{SMe})_{12}$ cluster 971 featuring the binding of $\mathrm{Hg}$ to the $\mathrm{Me}_{4}^{\mathrm{II}} \mathrm{Cys}_{12}-\alpha$ site of Mytilidae (MT2 reference). $\mathrm{f}$ ) $\left\{\mathrm{Hg}_{4} \mathrm{~S}_{12}\right\}$ 972 motif of $\beta$-HgS. g) Geometry-optimized $\mathrm{Hg}_{4}(\mathrm{SMe})_{10} \mathrm{His}$ cluster featuring the binding of $\mathrm{Hg}$ to the 973 proposed $\mathrm{Me}_{4}^{\mathrm{II}} \mathrm{Cys}_{10} \mathrm{His}$ site of Musa acuminata (banana) MT. ${ }^{95}$ The His for Cys substitution 974 marginally modifies the mercury-sulfur coordination. h) Geometry-optimized $\mathrm{Zn}_{5}(\mathrm{SMe})_{12}$ cluster 975 featuring the binding of $\mathrm{Hg}$ to the proposed $\mathrm{Me}^{\mathrm{II}}{ }_{5} \mathrm{Cys} 12$ cluster of Cicer arietinum (chickpea) MT. ${ }^{102}$ 976 The $\left\{\mathrm{ZnS}_{4}\right\}$ tetrahedron in the center links two edge-sharing $\mathrm{Zn}_{2}(\mathrm{SMe}) 12$ complexes. The heavily 977 strained $\mathrm{Hg}_{5}(\mathrm{SMe})_{12}$ cluster is unstable. Cartesian coordinates are given in the SI. 
979 Figure 8. a) $\mathrm{L}_{3}$-edge HR-XANES spectra of $\mathrm{Hg}_{\mathrm{x}} \mathrm{S}_{\mathrm{y}}$ clusters in plant leaf (Vn30) and in natural 980 organic matter (Hg-NOM spectrum from ref. $\left.{ }^{47}\right)$. The NOM was reacted with $200 \mathrm{ng} \mathrm{Hg(II)} \mathrm{mg}{ }^{-1}$ 981 NOM dwt at pH 6 in air-equilibrated water in the dark for 10 days. It contains 3-5 nanometer-sized $982 \beta$-HgS crystals imaged by HRTEM (insert). ${ }^{47}$ The modulations in the top-edge region (arrows) are 983 diagnostic of medium-range distance $\mathrm{Hg}-\mathrm{Hg}$ pairs. In their absence, the absorption signal has a 984 bell-shape (Figure 5). ${ }^{53}$ b) Polyhedral representation of a $\mathrm{Hg}_{7}(\mathrm{SMe}){ }_{16}$ cluster with a $\beta$ - $\mathrm{HgS}$-type 985 local structure. The $\left\{\mathrm{Hg}_{7} \mathrm{~S}_{16}\right\}^{34,35}$ motif is from the $\beta$-HgS structure, ${ }^{108}$ only the positions of the 986 methyl groups (Me) were optimized. Cartesian coordinates are given in the SI. 987 

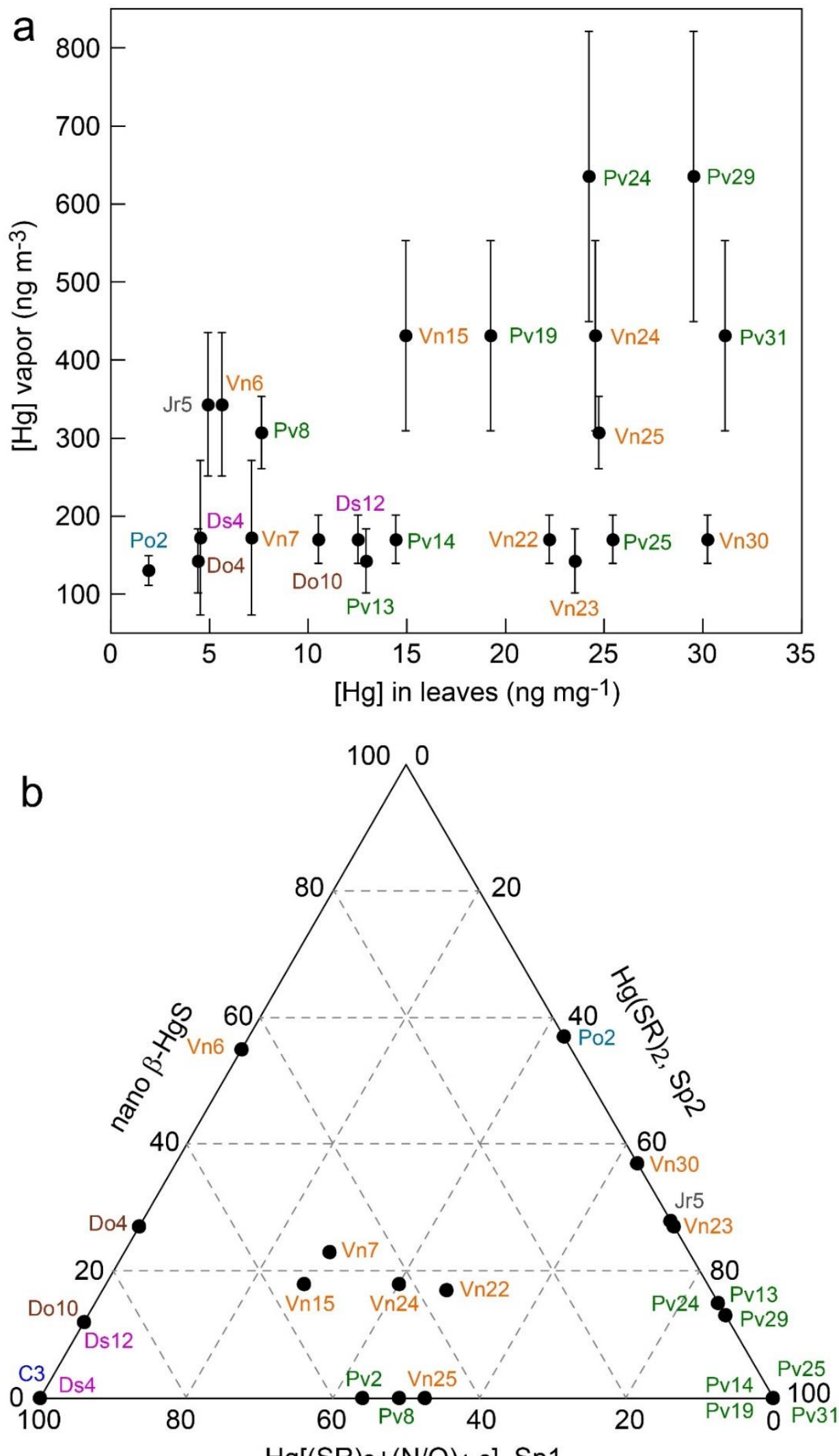


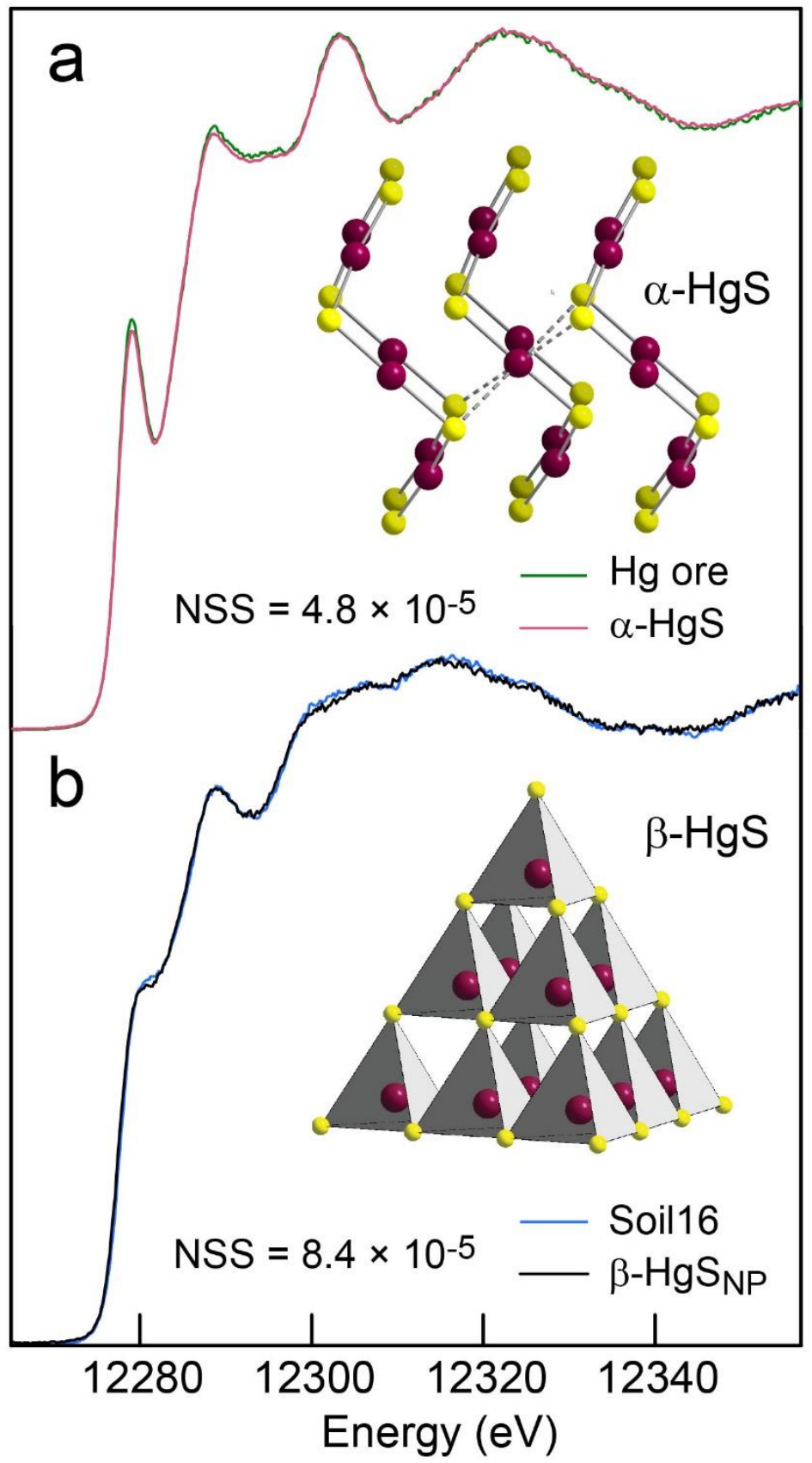

994

Figure 2

996

Please, print to fit the width of one column, thank you 


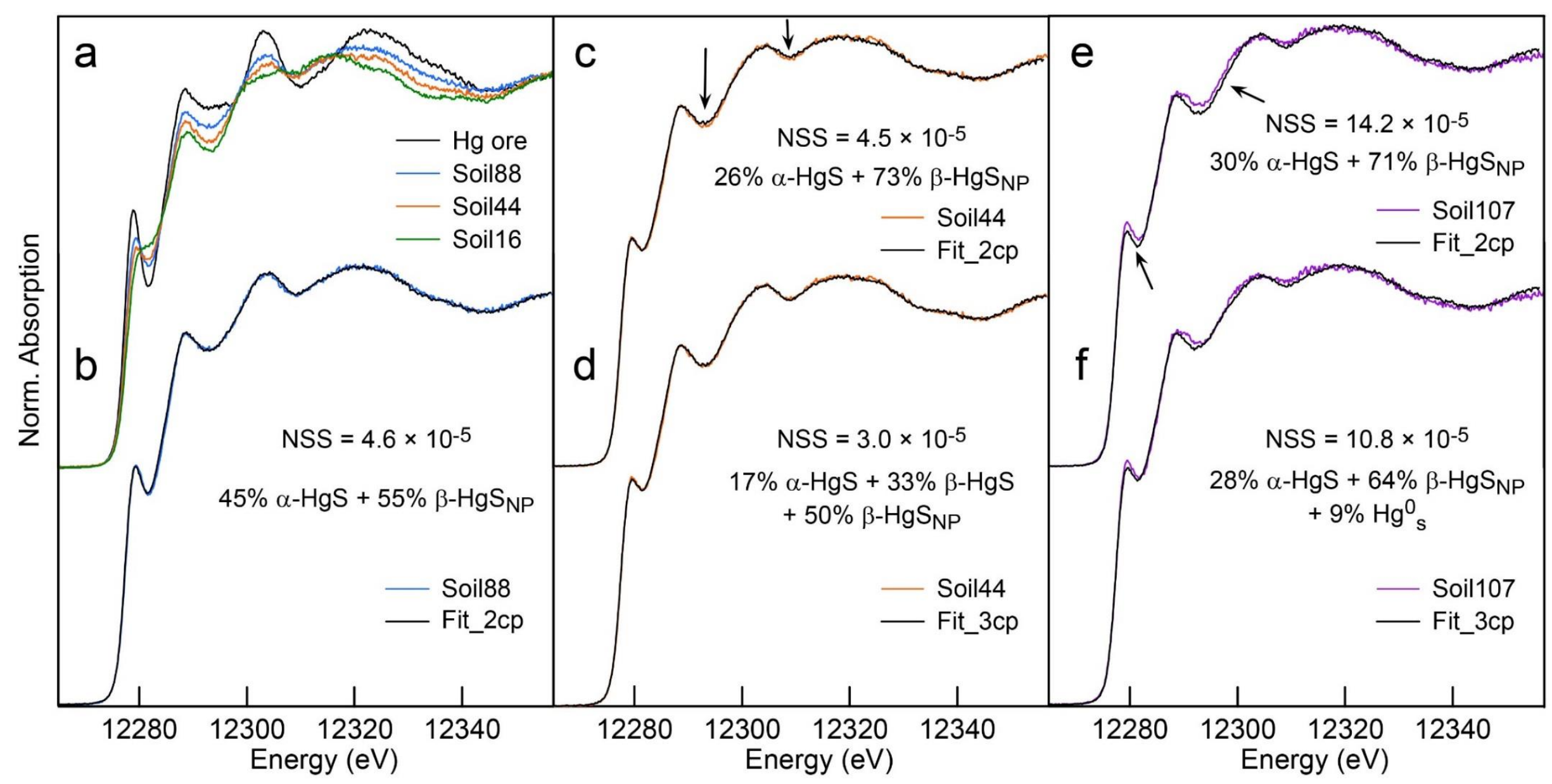

Figure 3

Please, print to fit the width of two columns, thank you 

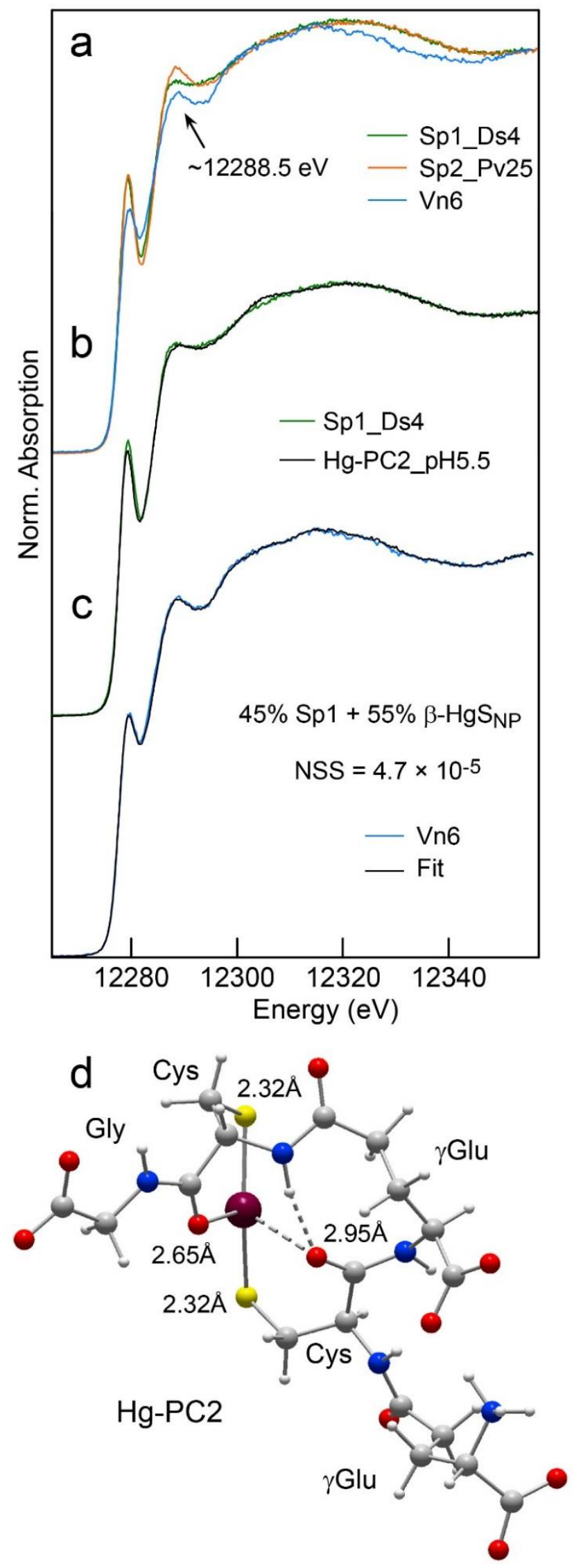

Figure 4

Please, print to fit the width of one column, thank you 


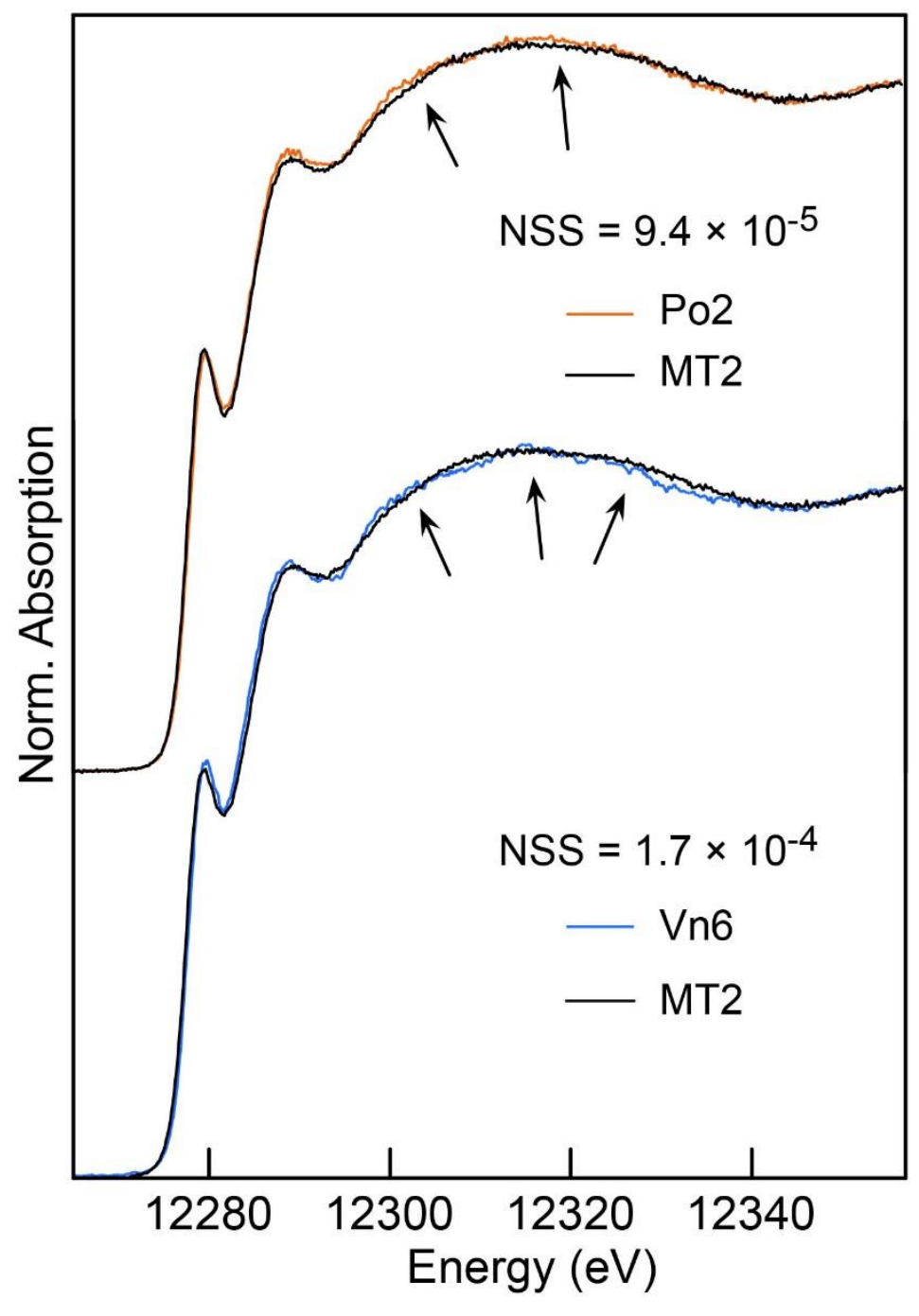

Figure 5

Please, print to fit the width of one column, thank you 

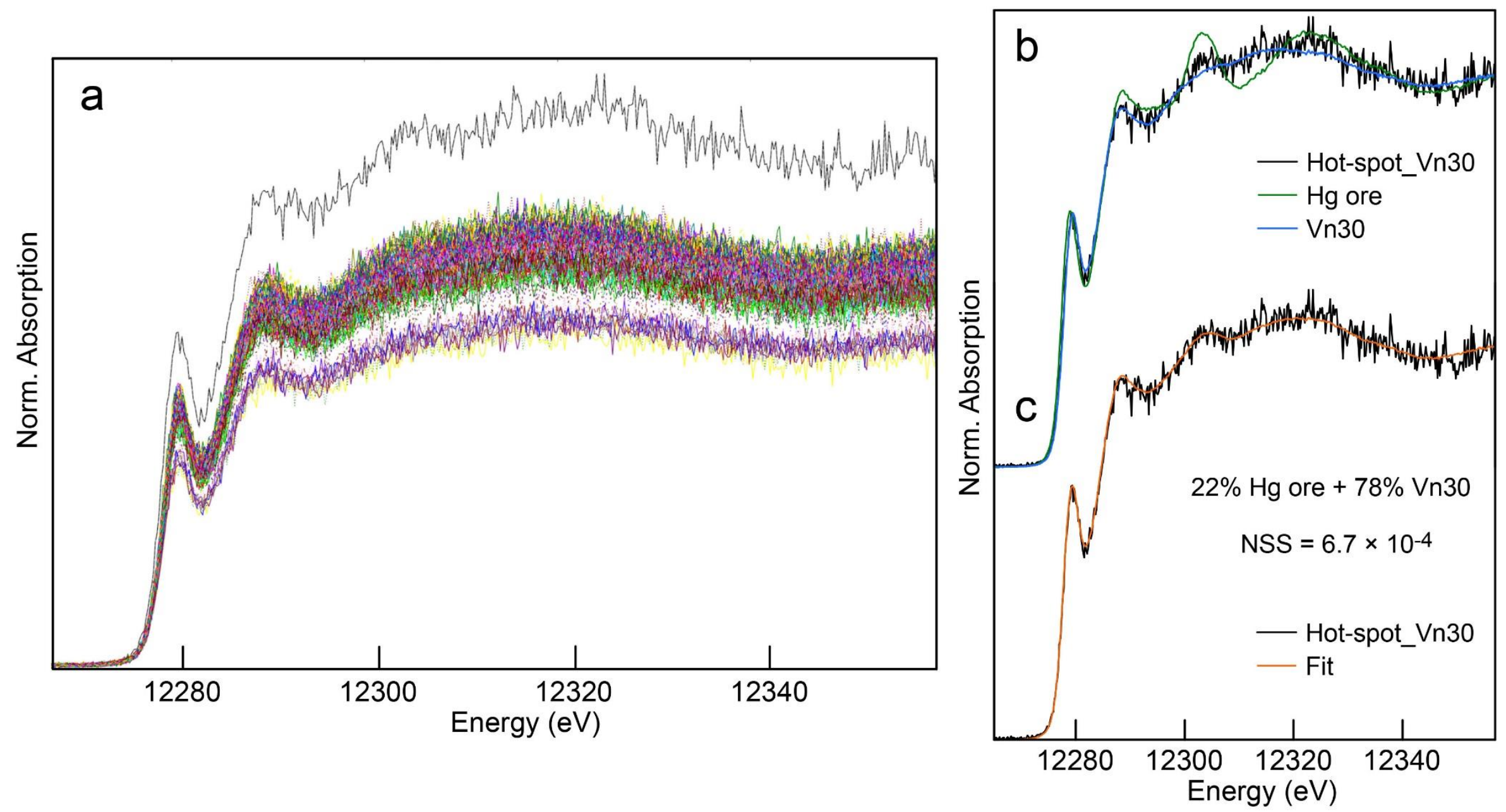

Figure 6

Please, print to fit the width of two columns, thank you 

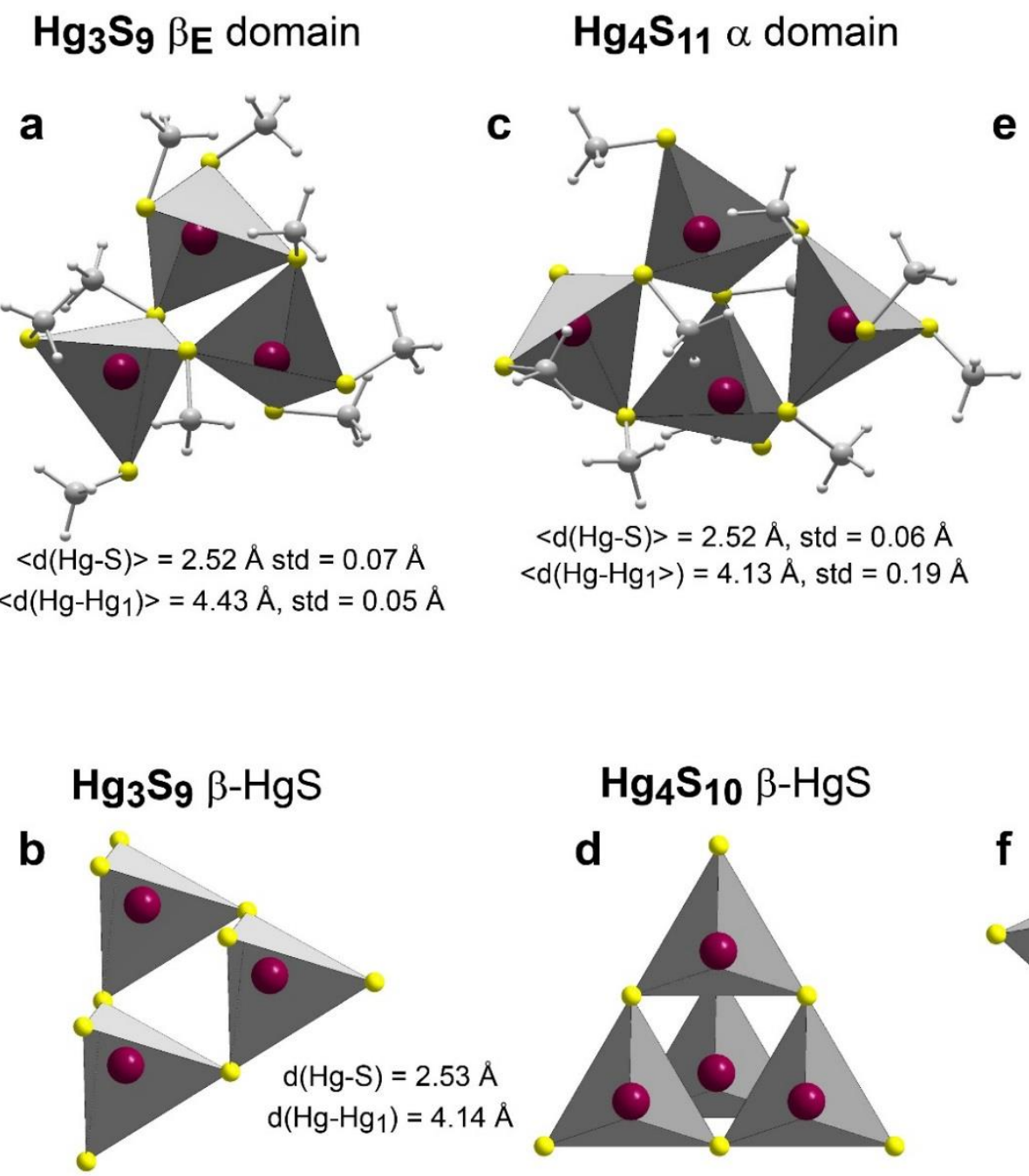

$\mathrm{Hg}_{4} \mathrm{~S}_{12} \alpha$ domain

e

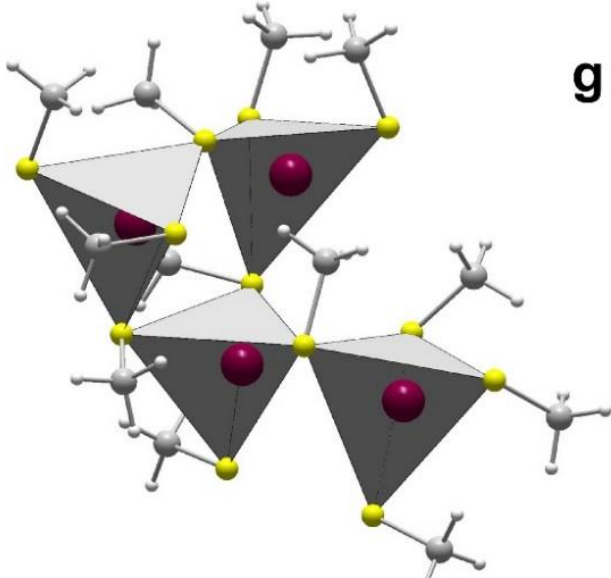

$<\mathrm{d}(\mathrm{Hg}-\mathrm{S})>=2.52 \AA$ std $=0.08 \AA$ $<\mathrm{d}\left(\mathrm{Hg}-\mathrm{Hg}_{1}\right)>=4.43 \AA$, std $=0.10 \AA$ $\mathrm{d}\left(\mathrm{Hg}-\mathrm{Hg}_{2}\right)=5.64 \AA$

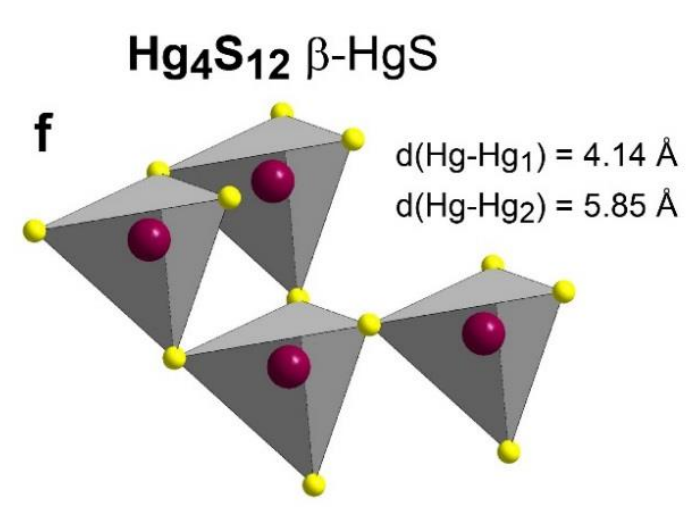

Figure 7
$\mathrm{Hg}_{4} \mathrm{~S}_{10} \mathrm{His}$

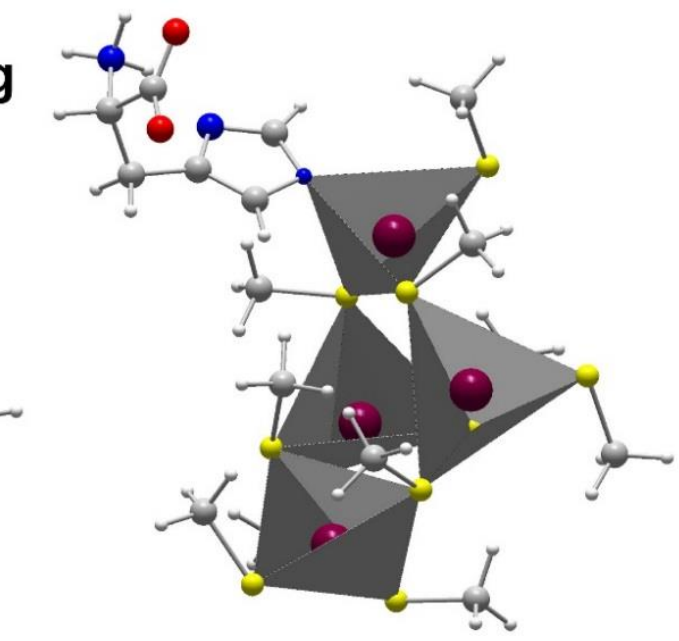

$<\mathrm{d}(\mathrm{Hg}-\mathrm{S})>=2.52 \AA, \mathrm{std}=0.08 \AA$ $<\mathrm{d}\left(\mathrm{Hg}-\mathrm{Hg}_{1}>\right)=4.07 \AA$, std $=0.20 \AA$ $\mathrm{d}\left(\mathrm{Hg}-\mathrm{Hg}_{2}\right)=6.60 \AA$

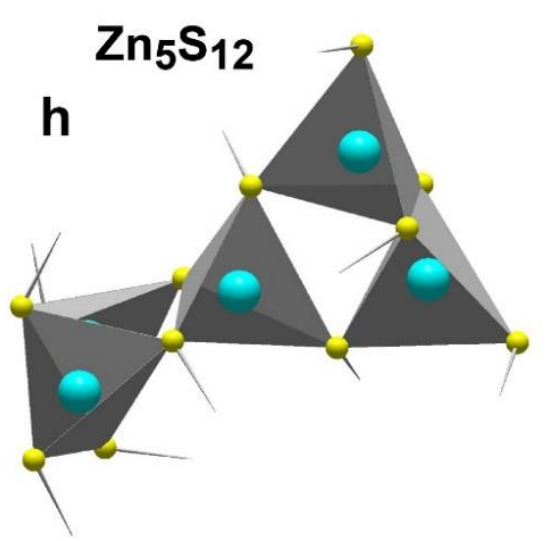

Please, print to fit the width of two columns, thank you 

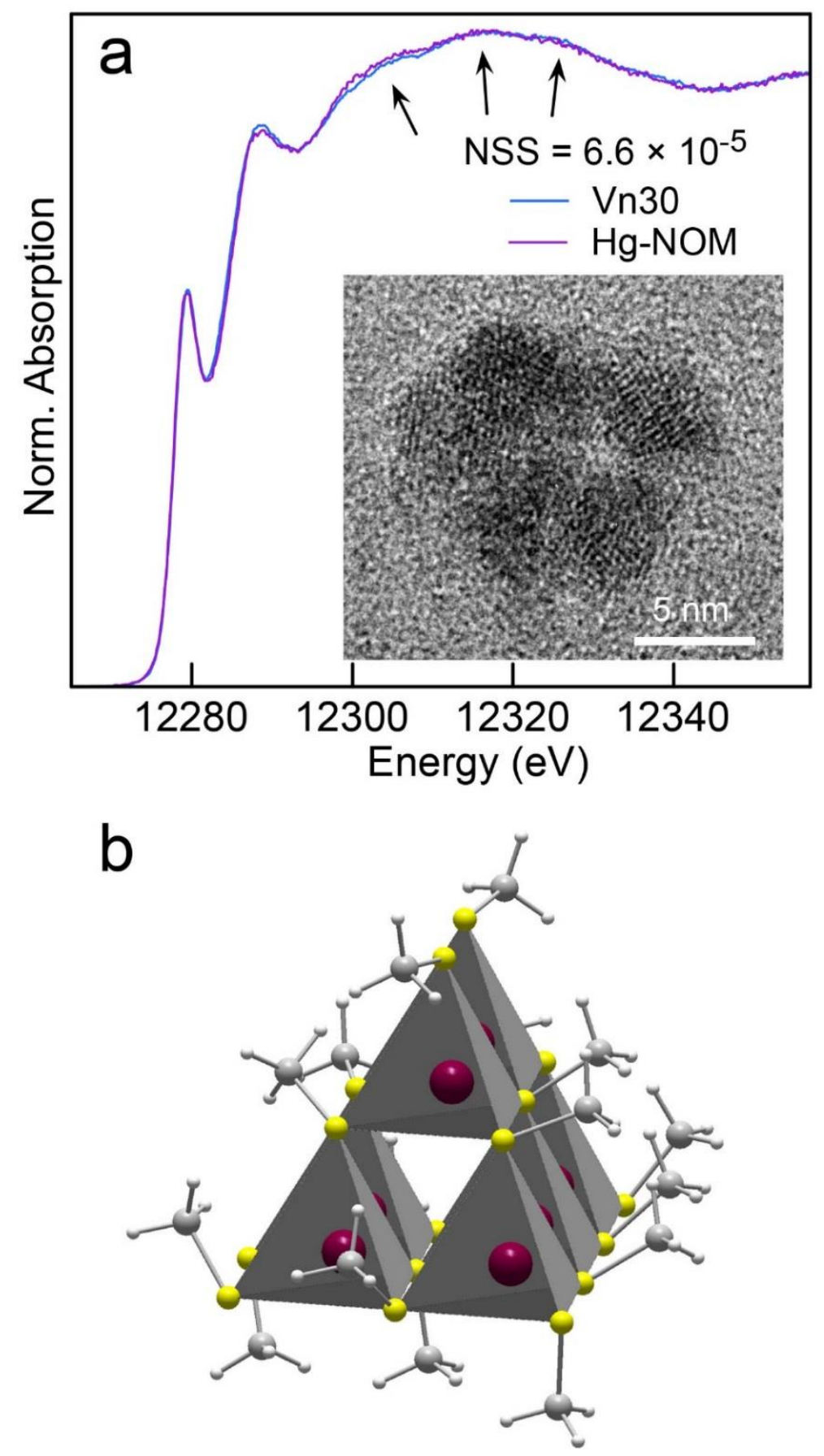

Figure 8

Please, print to fit the width of one column, thank you 